Original Research Article

\title{
Trace elements risk assessment for consumption of wild mussels along South Africa coastline
}

\author{
P.S. Nekhoroshkov ${ }^{a}{ }^{*}$, J. Bezuidenhout $^{\mathrm{b}}$, M.V. Frontasyeva ${ }^{\mathrm{a}}$, I.I. Zinicovscaia ${ }^{\mathrm{a}, \mathrm{c}}$, N.S. Yushin ${ }^{\mathrm{a}}$, \\ K.N. Vergel ${ }^{\mathrm{a}}$, L. Petrik ${ }^{\mathrm{d}}$ \\ ${ }^{\text {a }}$ Faculty of Military Science, Stellenbosch University, Victoria Street, Stellenbosch, South Africa \\ b Department of Nuclear Physics, Frank Laboratory of Neutron Physics, Joint Institute for Nuclear Research, Dubna, 141980, Russia \\ ${ }^{\mathrm{c}}$ Horia Hulubei National Institute for R\&D in Physics and Nuclear Engineering, 30 Reactorului Str. MG-6, Bucharest, Magurele, Romania \\ ${ }^{\mathrm{d}}$ Environmental and Nano Sciences (ENS) Research Group, Department of Chemistry, University of the Western Cape, Bellville, South Africa
}

\section{A R T I C L E I N F O}

\section{Keywords:}

Mussels

Food composition

Food analysis

Neutron activation analysis

South Africa

Health risks

Target hazardous quotient

\begin{abstract}
A B S T R A C T
The study aimed to contribute to the scarce data on concentrations in the soft tissue of wild mussels growing in coastal cities of South Africa. The intake of 26 micro and macroelements was estimated. The mass fractions of sample sets from 8 sites along the South African coast from the West (Port Nolloth) to the East (Durban) were studied by neutron activation analysis at the Joint Institute for Nuclear Research (Russia). The following elements were identified as potentially hazardous due to high consumption risks: $\mathrm{Al}, \mathrm{Cr}, \mathrm{Co}, \mathrm{Zn}, \mathrm{As}$, and I at stations in the Cape Town area (Waterfront, Hout Bay) and Durban. The mean concentrations of these elements among all individuals were 208, 0.8, 0.46, 60, 2.6, and $11 \mathrm{ppm}$ of wet weight, respectively. In the studied mussels, the concentrations of $\mathrm{Cr}, \mathrm{Zn}$, As, and Se (ranging between $0.2-2.8,14-290,1.6-4.6$, and $0.31-2.4 \mathrm{ppm}$ of wet weight, respectively) exceeded maximum permissible levels for fish products. The weekly consumption of more than $250 \mathrm{~g}$ of fresh mussels per person could increase the risk for human health by potential intake of such elements as $\mathrm{Al}$, As, and I.
\end{abstract}

\section{Introduction}

\subsection{Significance of mussels in South Africa}

Coastal resources in South Africa are vital for local coastal communities that depend on them, as many live in abject poverty. Mussel meat is the most accessible source of natural food besides fish. However, mussels, as organisms that filtrate the water, could accumulate high concentrations of trace or other elements originating from coastal sources of pollution. It was estimated that in South Africa, $58 \%$ of the coastal and inshore ecosystem types, $41 \%$ of the offshore ecosystem types, and $43 \%$ of the estuary ecosystem types are threatened by pollution (Van Niekerk and Turpie, 2012). Mussels are benthic organisms that act as ecosystem engineers in the coastal zones and as attached molluscs, they improve the quality of water, food, and substrate basis of the ecosystem.

Mussels can reflect levels of trace elements present in seawater and seston due to natural inputs and anthropogenic activities. Wastewater discharges are the main source of local pollution in coastal municipalities. They contain high levels of toxic elements that could increase in the number of harmful events associated with bioaccumulation in marine organisms, resulting in the fall of populations and pose risk to human health. It is generally acknowledged that since 2004, the increasing human population in coastal regions has certainly resulted in further significant increases in the volumes of domestic sewage and municipal wastewater discharge in the sea (Sink et al., 2012). In South

Abbreviations: BW, body weight (kg); CF, conversion factor; CR, consumption rate (g/week or g/day); DW, dry weight; EDI, estimated daily intake ( $\mu \mathrm{g} / \mathrm{kg}$ bw/ day); EPA'sIRIS, Environmental Protection Agency's Integrated Risk Information System; EWI, estimated weekly intake ( $\mu \mathrm{g} / \mathrm{kg}$ bw/week); HI, total hazardous index; JECFA, Joint FAO/WHO Expert Committee on Food Additives; LOAEL, lowest-observed-adverse-effect level; MPCR, maximal permissible consumption rate (calculated according to study) (kg); MPL, maximum permissible level ( $\mu \mathrm{g} / \mathrm{g}$ w.w.); NOAEL, no-observed-adverse-effect level; PTWI, provisional tolerable weekly intake (mg/kg b.w./week); PMTDI, provisional maximum tolerable daily intake (in this study in $\mu \mathrm{g} / \mathrm{kg}$ b.w./ day); RfD, oral reference dose ( $\mu \mathrm{g} / \mathrm{kg}$ bw/day); RQ, risk quotient; TDI, tolerable daily intake (in this study in $\mu \mathrm{g} / \mathrm{kg}$ b.w./day); THQ, target hazardous quotient; WW, wet weight.

* Corresponding author.

E-mail address: nekhoroshkov@jinr.ru (P.S. Nekhoroshkov). 
Africa preliminarily treated sewage, secondary treated effluent discharges in the surf zone and estuaries, and untreated sewage from informal settlements occurring in stormwater runoff are discharged into the marine environment. Stormwater runoff from urban areas is difficult to control or predict since it is heavily dependent on rainfall which is collected and channeled from polluted surfaces into outlets and eventually to beaches or rocks, where the mussels can catch different types of particles and bioconcentrate the ions of metals directly from the water.

Historical data about the concentration of elements in mussels along South Africa are extremely limited. The fragmented results of local studies could not be merged into one dataset. Nowadays, there is no national monitoring program focusing on the assessment of industrial and urban pollution influence on mussels and human health via consumption of local mussels at South African coastline.

The use of high amounts of mussel meat for food in coastal municipalities is justified by the high protein content. However, the amounts of microelements can vary widely between polluted and pristine local areas. Analysis of the total content of a wide range of elements in mussels could be a useful approach to assessing differences in the levels of toxic and other trace elements at a regional scale.

\subsection{Consumption of mussels}

Consumption of mussels provides proteins, essential minerals, and vitamins, and thus, some protection from certain diseases related to nutritional deficiencies the risks, and benefits of their consumption are still hard to assess because of the level of metals bioaccumulated from the marine environment, with their reviewed toxicity (Gupta and Singh, 2011). It is important to know the diet-related hazard for the local population, which uses natural indigenous mussel meat as a main dish.

There are several approaches to evaluate the amounts of weekly or daily consumption per person around the world. In statistical reports in different countries, the average consumption of seafood (shellfish group) per capita usually is used. In South Africa, approximately 312,000 tonnes of seafood is eaten annually, with per capita seafood consumption at $6.25 \mathrm{~kg}$ in 2010 (Hofherr et al., 2016). But this approach does not take into account the local population in coastal cities, in which the citizens can eat mussels in huge quantities as a main dish. In regional studies, the consumption of mussels varies greatly. Ferrara et al., 2001 set the consumption of molluscs for the general population in the range of $20-40 \mathrm{~g} /$ person/day and strong social seafood consumers in the range of $150-270 \mathrm{~g} /$ day/person. Whyte et al., 2009 reported that the values of recommended and real consumption of mussels by New Zealand local populations range between $3.2 \mathrm{~g}$ (for average citizens) and $160 \mathrm{~g}$ per day (for Maori). Storelli and Marcotrigiano (2001) proposed that the consumption levels of bivalve molluscs per capita differ among geographical regions of Italy and range from 0.8 to $3.6 \mathrm{~g} / \mathrm{d}$. This corresponds to less than 2 individuals of mussels per week and that is the low-level consumption group. Stankovic et al., 2012, set the consumption of mussels at $28.6 \mathrm{~g}(17.8-35.7)$ per person per day to calculate TDI for the low consumption group. Ho and Leung (2014) considered the consumption of molluscs per capita for Hong Kong at the level of $52 \mathrm{~g} / \mathrm{d}$ (Ho and Leung, 2014) that is considerably higher than the average values in the country according to reports of FAO. The official consumption of molluscs for a country is typically underestimated. For example, for South Africa from 2014 to 2017, it was $0.22-0.11 \mathrm{~kg}$ per year (that means $0.6-0.3 \mathrm{~g}$ per day) with a minimum value of $0.07 \mathrm{~kg} / \mathrm{person} / \mathrm{yr}$ in 2015 (FAOSTAT, 2017). Average consumption in European countries is higher and ranges from 1.17 to $3.94 \mathrm{~kg}$ per inhabitant per year. All these values included the entire population with its continental part, but locals in the coastal regions consumed more seafood (and bivalve molluscs). Although the average consumption throughout a person's life (per capita) is on average extremely low (average molluscs consumption per capita in South Africa from 2014 to 2017 ranged from 0.07 to $0.22 \mathrm{~kg} /$ person/year - FAOSTAT, 2017), mussel consumption was not regulated in coastal areas. Consequently, the daily dose can be increased to one hundred grams per person per day, contained in one dish (which corresponds to one cup of mussels and consists of 7-15 individuals, depending on their size).

In our study, we deemed that the average value of mussel soft tissue consumed as human food should be set at about $200 \mathrm{~g}$ weekly per person ( $28.6 \mathrm{~g}$ per day) based on the study by Stankovic et al., 2012. This is close to real consumption rates taking into account the size of average dishes in coastal cities, according to our experience. It corresponds to the amount of soft tissue (meat) of several mussels that one person can eat per day on average.

\subsection{Application of mussels in risk assessment}

The hot spots of coastal pollution associated with the status of local mussels, based on a balance of anthropogenic pressure and adaptation processes through self-purification, should be taken into consideration in coastal management and selection of the location for future farms. Key pollution areas and elemental groups which could affect the health of the local population can be estimated by different elemental ratios and calculation of risk assessment indices.

Mussels are a local self-caught seafood group as identified by the World health organization (WHO). This group is important because of insufficient data about intakes of elements through the group of typical seafood in human organisms of inhabitants of local cities. Thus, it is an unexplored potential health risk factor. Mussels have high bioaccumulation and a low biotransformation potential for both organic and inorganic contaminants. They are suitable long-term bioaccumulators (Smolders et al., 2003).

When mussels are exposed to pollutants, three distinct phases in stress response could be observed: alarm, compensation, and exhaustion, which correspond to alterations at the biochemical and physiological levels, and finally effects in the whole organism (Smolders et al., 2003). The last stage can be detected by changes in internal concentrations of a given element in the whole body. Mussels could be used as biomonitors with long-term exposure (years), which fits well for the purposes of prolonged risk assessment studies as they are used repeatedly as food.

The Mussel Watch Program, as part of the South African National Committee for Oceanographic Research (SANCOR) and the Marine Pollution Research Programme (MPRP), has been active since 1985, but the effects have not been reported regularly and in full (Sparks et al., 2014). It was based on the estimation of the concentration of 7 elements $(\mathrm{Cu}, \mathrm{Cd}, \mathrm{Pb}, \mathrm{Zn}, \mathrm{Hg}, \mathrm{Fe})$ in blue alien mussel Mytilus galloprovincialis on the West Coast (Saldanha Bay, Cape Town). The data about concentrations of hazardous metals and parameters of mussels at the West coast of South Africa were partially presented in Clark et al. (2017). Greenfield et al. (2011) reported data for brown mussel Perna perna - at the East coast (Richard Bay) for the period from 1976 to 2009.

(Wepener and Degger, 2020) showed results of mussel surveys conducted in 2008 and 2009, which were performed using brown mussels (Perna perna) at navigational buoys from the harbors along the South African coast (from Cape Town to Richard Bay). Their study showed that metal concentrations significantly decreased (by one or two orders of magnitude) from 2008 to 2009 , which was explained by variabilities of non-point discharges of metals into the harbors and larger-scale oceanographic changes in upwelling events. (Erasmus et al., 2020) assessed the biogeographical differences of trace element accumulation in mussels (Perna perna) between the subtropical and warm temperate, at the beaches of the East Coast (Sheffield Beach and Tsitsikamma Marine Protected Area).

In general, fragmented data about concentrations of a small number of microelements in mussels as biomonitors were presented for different locations and regions without assessing the level of marine pollution and the influence of urban and industrial activity on human health along the whole South African coastline (Farrington et al., 2016). It is important to note that risk assessment studies were not conducted during large-scale 
mussel biomonitoring investigations.

Numerous studies on the concentration of trace elements in mussels assessed risks associated with their consumption collected in the world regions of modern large-scale producers of cultivated molluscs (for example, Montenegro, Turkey, China, USA, Italy, New Zeland, Malaysia: Stankovic et al., 2012; Bat et al., 2018; Fung et al., 2004; Ho and Leung, 2014; Goldhaber, 2003; Spada et al., 2013; Whyte et al., 2009; Yap et al., 2016). Usually, they focused on key pollutants, namely, on four trace elements ( $\mathrm{Cd}, \mathrm{Pb}, \mathrm{Hg}$, and $\mathrm{As}$ ) and discussed their concentrations in mussels in comparison with guideline limits.

In South Africa, the mussels were earlier studied by direct comparison of the concentration of a small set of elements with maximum permissible levels. Other studies were focused on the species specificity (Firth et al., 2019) in the bioaccumulation of elements or intakes of other pollutants (microplastics, organic pollutants, etc.) (Li et al., 2016). However, studies on marine mussels' contamination with metals around the African coast, especially related to human health risks through consumption, are very limited, and further research is needed to ensure that mussels do not pose unknown risks to consumer health.

In our study, the impact on human health in this study was assessed by the most commonly used risk indexes (such as RQ, THQ, HI) based on the maximum concentration of elements that could be reached via consumption of mussels. The nutritional value of selected elements with a constant diet was not considered. The main task was to estimate the hazardous levels of consumption of elements according to international guidelines in various south African coastal cities based on their concentrations in one of the main food sources - mussels.

\section{Material and methods}

\subsection{Sampling}

The samples of mussels were collected by hand from 8 sites (stations) along the South African coastline (Fig. 1, Table 1) in 2017 out of the spawning season. The water temperatures during sampling were in the typical ranges for the studied regions (Table 1 ).

The stations were chosen as the most representative in terms of availability of mussels, natural environment, and typical ecological conditions among the coastal regions of South Africa.
Four closely located stations $(2,3,4,5)$ with known sources of pollution (grey wastewater discharge) in Saldanha Bay (2 - Bok river and 3 - Strandloper) and Cape Town region (4 - Waterfront, 5 - Hout Bay) were included in the study due to the known local pollution features for the purposes of comparison with the rest. From each site, mussels with a size of $40-80 \mathrm{~cm}$ were collected by hand from different local spots with $2 \mathrm{~m}$ distance. The samples were collected by taking into account the availability of mussels and their substrates (rocks), so as to be representative of the whole coastal population. $90 \%$ of the mussels were Mytilus galloprovincialis. For comparison of concentrations on a wet weight basis, in our study for all samples, we have used the average conversion factor of batch mussels from Saldanha Bay, which corresponded to 0.32 dry/wet weight. The use of an average value simplifies the conversion and enables an easier comparison of the data with that by other researchers. After collection, the samples were frozen for transportation.

Description of stations:

St. 1. Port Nolloth: It is an isolated (very far from other cities) small town that was founded around the offshore diamond industry. Samples were collected under a jetty open to the ocean.

St. 2. Bok River: This site is located in Saldanha Bay near the greywater outlet of the city of Saldanha.

St. 3. Strandloper: This site is located in Saldanha Bay at the greywater outlet of the neighboring town of Langebaan.

St. 4.Waterfront: This site is located on a breakwater on the Cape Town waterfront that is exposed to the ocean.

St. 5. Hout Bay: This site is located in Hoot Bay, at the greywater outlet of the city.

St. 6. Plettenberg Bay: The exact sampling site was on the rocks in the middle of the city's main beach. The area is not densely populated and does not appear polluted.

St. 7. Port Elizabeth: This site is on the dock in the middle of Port Elizabeth's main beach. The area is densely populated and appears affected by pollution, as it is located near a large industrial port.

St. 8. Durban: The sampling site is on the mouth of South Africa's busiest industrial port and, according to numerous studies, the area is "heavily polluted".

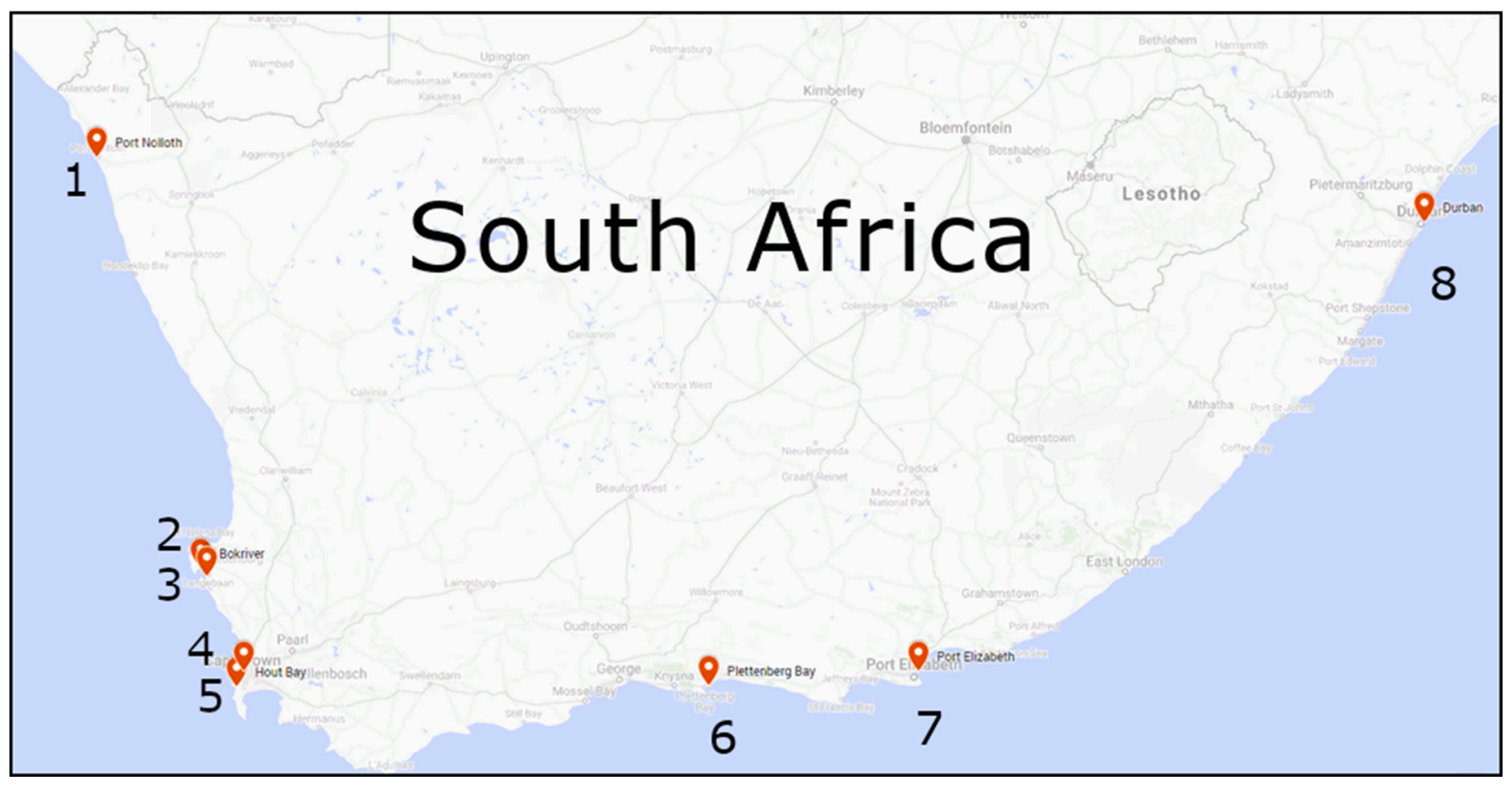

Fig. 1. Sampling sites along the South African coast in 2018. 
Table 1

Number of mussels and characteristics of sampling sites.

\begin{tabular}{|c|c|c|c|c|c|c|}
\hline № & Station (West-East) & Number of individuals in sets & Population of the city ${ }^{a}$ (2011) & Ocean & Temperature ${ }^{\mathrm{b}},{ }^{\circ} \mathrm{C}$ & Salinity ${ }^{\mathrm{b}}$, PSU \\
\hline 1 & Port Nolloth & 12 & 6092 & Atlantic & $11-18$ & $34.7-35.4$ \\
\hline 2 & Bok River & 10 & $99000 *$ & Atlantic & $11-18$ & $34.7-37$ \\
\hline 3 & Strandloper & 10 & $99000^{*}$ & Atlantic & $11-18$ & $34.7-37$ \\
\hline 4 & Waterfront & 12 & $433688^{* *}$ & Atlantic & $11-18$ & $34.7-37$ \\
\hline 5 & Hout Bay & 12 & 17900 & Atlantic & $11-18$ & $34.7-37$ \\
\hline 6 & Plettenberg Bay & 12 & 31804 & Indian & $13.5-23$ & 35.4 \\
\hline 7 & Port Elizabeth & 12 & 312392 & Indian & $13.5-23$ & 35.4 \\
\hline 8 & Durban & 12 & 595061 & Indian & $16-27$ & $>35.4$ \\
\hline
\end{tabular}

* Saldanha Bay Local Municipality.

** Population of the Cape Town city.

a Population data from Statistics South Africa, 2012.

b Average regional data from RSA-DEA, 2018, particularly Smit et al., 2013.

\subsection{Elemental analysis}

The concentrations of 26 elements were determined by instrumental neutron activation analysis at the REGATA facility of the IBR-2 reactor, JINR (Dubna, Russia).

From each local batch of samples, 10-12 mussels of one size group were chosen. The number of mussels was determined based on the minimum number of individuals per sampling site, necessary, on the one hand, for the representativeness of the subsample, and on the other hand, to minimize the deviations within the group. Also, the removal of such a small amount of mussels (corresponding to about one average daily serving) does not harm the natural population.

Each individual was defrosted and dissected to shells and soft tissues. After that, the soft tissues were rinsed with deionized water to remove mud and sediments and other particles, lyophilized to constant weight, pulverized to powder using a planetary mono mill with agate milling balls (PULVERISETTE 6, Fritsch Laboratory Instruments GmbH, Germany) at $400 \mathrm{rpm}$. The homogenized mussel soft tissues $(0.3 \mathrm{~g})$ were packed into plastic bags for the determination of short-lived isotopes and aluminum cups for long-lived isotopes of elements.

The instrumental neutron activation analysis was performed differently for 3 groups of elements according to the determination types: short-lived isotopes ( $\mathrm{Mg}, \mathrm{Al}, \mathrm{S}, \mathrm{Cl}, \mathrm{Ca}, \mathrm{Ti}, \mathrm{V}, \mathrm{Mn}, \mathrm{I}$ ) - subsamples were irradiated with full spectra of neutrons in the channel at a neutron flux of $1.6 \cdot 10^{12} \mathrm{n} \mathrm{cm}^{-2} \mathrm{~s}^{-1}$ during $3 \mathrm{~min}$, after $3 \mathrm{~min}$ decay they were measured for $15 \mathrm{~min}$; long-lived isotopes - samples were irradiated with epithermal neutrons in another irradiation channel with a cadmium shield at a neutron flux of $3.31 \cdot 10^{11} \mathrm{~cm}^{-2} \mathrm{~s}^{-1}$ for 3 days, after 3 and 20 days of decay they were measured for $30 \mathrm{~min}$ (for such elements as $\mathrm{Na}, \mathrm{K}, \mathrm{As}, \mathrm{Br}$, and $\mathrm{U}$ ) and $90 \mathrm{~min}$ (for $\mathrm{Sc}, \mathrm{Cr}, \mathrm{Fe}, \mathrm{Co}, \mathrm{Ni}, \mathrm{Zn}, \mathrm{Se}, \mathrm{Rb}, \mathrm{Sr}, \mathrm{Sb}, \mathrm{Cs}$, and $\mathrm{Th}$ ), respectively.

The spectra of induced gamma activity were measured with HPGe detectors (Canberra) with a resolution of $1.9 \mathrm{keV}$ for the totalabsorption peak of $1332 \mathrm{keV}$ of ${ }^{60} \mathrm{Co}$. The detector is calibrated using standard spectrometric and certified reference materials (Pavlov et al., 2016). The detailed procedure of neutron activation analysis, performed at the REGATA facility, was described by Frontasyeva, 2005.

For quality control assurance (Table 2), standard reference materials of different origin provided by the National Institute of Standards and Technology (NIST) and Institute for Reference Materials and Measurements (IRMM) were used: NIST1633c (coal fly ash), NIST1547 (peach leaves), NIST1632c (trace elements in coal), IRMM690cc (calcareous soil), NIST2710, NIST2710a (Montana soil), NIST2709 (trace elements in soil), NIST1572 (citrus leaves), and NIST1566b (oyster tissue). The use of standards of different matrixes allowed to expand the number of elements with certified values, which can be determined in mussel samples, since the standard material for oyster tissue (1566b) contains only a limited number of certified values. Chemical matrix effects, known to be significant sources of error in some other types of instrumental chemical analysis, are insignificant in NAA. The use of reference

materials with the matrix different from the analyzed samples in NAA is explained by insignificant matrix effect in case of small samples (size and weight) (Greenberg et al., 2011).

Specialized software developed in FLNP JINR (Pavlov et al., 2016) was used to create a Group Standard Sample (GSS) from all above-mentioned reference materials to calculate the content of 26 elements in the analyzed samples with maximum accuracy. The GSS was used to check the quality of the analysis by determining the content of the same elements. This procedure, applied to SRMs, allowed to compare the obtained values with the certified and provided quality control of the analysis (Zinicovscaia et al., 2018).

The majority of elements were in the range of $10 \%$ of deviation between determined and certified values. Selenium was determined near detection limit levels and their mean concentrations among sample sets were with high standard deviations (71 \% of mean recovery). Several elements were excluded from consideration due to the lack of reference data on concentrations in mussels and their tolerable intakes (PTWI and RfD).

\subsection{Statistics}

Element concentrations were determined on a dry weight basis for each individual of mussels, and then by using the conversion factor the minimum, maximum, mean values, and standard deviations were calculated on a wet weight basis for each batch.

All data sets were tested for normality and homogeneity of variance by using Shapiro-Wilk and Levene's tests respectively in STATISTICA software. The majority of elements were not normally distributed ( $\mathrm{p}<0.05$ except $\mathrm{Cl}$ and $\mathrm{K}$ ), thus the nonparametric Kruskal-Wallis test (Zar, 1984) was applied to examine the significance of differences of the determined concentrations of elements in mussel tissues among stations. For the calculation of key ratios, the maximum values in each set were used with attention to outliers.

Principal component analysis (PCA) was applied for the differentiation of groups of elements and identification of their contribution at the stations to demonstrate suggested sources.

\subsection{Human health risk assessment}

The information on hazard, exposure, and dose-response was combined to provide an estimate of the likelihood that any of the identified adverse effects will occur in exposed people. The environmental health risk was assessed by comparing the environmental status, as represented by the concentrations of the metals in mussels, and threshold values likely to cause adverse effects in human consumers. In this context, a risk quotient can be calculated as follows (based on Jovic et al., 2012; Yap et al., 2016; Korkmaz et al., 2017): 
Table 2

Quality control of Neutron Activation Analysis used in the present study.

\begin{tabular}{|c|c|c|c|c|}
\hline & SRMs & $\begin{array}{l}\text { Determined } \\
\text { concentrations, } \\
\mathrm{mg} / \mathrm{kg}\end{array}$ & $\begin{array}{l}\text { Certified } \\
\text { concentrations, } \\
\mathrm{mg} / \mathrm{kg}\end{array}$ & $\begin{array}{l}\text { Recoveries, } \\
\%\end{array}$ \\
\hline $\mathrm{Na}$ & $\begin{array}{l}\text { 1633c (coal fly } \\
\text { ash) }\end{array}$ & $1580 \pm 150$ & $1700 \pm 60$ & 92 \\
\hline $\mathrm{Mg}$ & $\begin{array}{l}1547 \text { (peach } \\
\text { leaves) }\end{array}$ & $4870 \pm 330$ & $4320 \pm 80$ & 111 \\
\hline $\mathrm{Al}$ & $\begin{array}{l}1547 \text { (peach } \\
\text { leaves) }\end{array}$ & $260 \pm 12$ & $250 \pm 8$ & 106 \\
\hline S & $\begin{array}{l}1632 c \text { (trace } \\
\text { elements in } \\
\text { coal) }\end{array}$ & $14900 \pm 970$ & $14620 \pm 600$ & 102 \\
\hline $\mathrm{Cl}$ & $\begin{array}{l}1547 \text { (peach } \\
\text { leaves) }\end{array}$ & $320 \pm 30$ & $360 \pm 20$ & 88 \\
\hline K & $\begin{array}{l}\text { 1632c (trace } \\
\text { elements in } \\
\text { coal) }\end{array}$ & $1060 \pm 200$ & $1100 \pm 30$ & 96 \\
\hline $\mathrm{Ca}$ & $\begin{array}{l}1547 \text { (peach } \\
\text { leaves) }\end{array}$ & $16400 \pm 1820$ & $15600 \pm 200$ & 105 \\
\hline Sc & $\begin{array}{l}690 \mathrm{cc} \\
\text { (calcareous } \\
\text { soil) }\end{array}$ & $8.4 \pm 0.2$ & $7.9 \pm 0.9$ & 106 \\
\hline $\mathrm{Ti}$ & $\begin{array}{l}2710 \\
\text { (Montana soil) }\end{array}$ & $2920 \pm 370$ & $2830 \pm 100$ & 103 \\
\hline V & $\begin{array}{l}2710 \\
\text { (Montana soil) }\end{array}$ & $70 \pm 4$ & $80 \pm 2$ & 94 \\
\hline $\mathrm{Cr}$ & $\begin{array}{l}2709 \text { (trace } \\
\text { elements in } \\
\text { soil) }\end{array}$ & $128 \pm 7$ & $130 \pm 4$ & 99 \\
\hline $\mathrm{Mn}$ & $\begin{array}{l}1572 \text { (citrus } \\
\text { leaves) }\end{array}$ & $24 \pm 2$ & $23 \pm 2$ & 102 \\
\hline $\mathrm{Fe}$ & $\begin{array}{l}2709 \text { (trace } \\
\text { elements in } \\
\text { soil) }\end{array}$ & $34000 \pm 1600$ & $35000 \pm 1100$ & 97 \\
\hline Co & $\begin{array}{l}\text { 1632c (trace } \\
\text { elements in } \\
\text { coal) }\end{array}$ & $3.4 \pm 0.1$ & $3.5 \pm 0.2$ & 99 \\
\hline $\mathrm{Ni}$ & $\begin{array}{l}2709 \text { (trace } \\
\text { elements in } \\
\text { soil) }\end{array}$ & $80 \pm 5$ & $88 \pm 5$ & 91 \\
\hline $\mathrm{Zn}$ & $\begin{array}{l}2709 \text { (trace } \\
\text { elements in } \\
\text { soil) }\end{array}$ & $101 \pm 4$ & $106 \pm 3$ & 96 \\
\hline As & $\begin{array}{l}1632 \mathrm{c} \text { (trace } \\
\text { elements in } \\
\text { coal) }\end{array}$ & $6.5 \pm 0.4$ & $6.2 \pm 0.3$ & 105 \\
\hline Se & $\begin{array}{l}2710 a \\
\text { (Montana soil) }\end{array}$ & $0.76 \pm 0.18$ & $1.0 \pm 0.3$ & 76 \\
\hline $\mathrm{Br}$ & $\begin{array}{l}1632 c \text { (trace } \\
\text { elements in } \\
\text { coal) }\end{array}$ & $7.9 \pm 3.3$ & $8.2 \pm 0.4$ & 97 \\
\hline $\mathrm{Rb}$ & $\begin{array}{l}1632 c \text { (trace } \\
\text { elements in } \\
\text { coal) }\end{array}$ & $7.9 \pm 1.5$ & $7.5 \pm 0.3$ & 106 \\
\hline $\mathrm{Sr}$ & $\begin{array}{l}1632 c \text { (trace } \\
\text { elements in } \\
\text { coal) }\end{array}$ & $64 \pm 5$ & $64 \pm 1$ & 100 \\
\hline $\mathrm{Sb}$ & $\begin{array}{l}2709 \text { (trace } \\
\text { elements in } \\
\text { soil) }\end{array}$ & $7.7 \pm 0.3$ & $7.9 \pm 0.6$ & 98 \\
\hline I & $\begin{array}{l}1547 \text { (peach } \\
\text { leaves) }\end{array}$ & $0.29 \pm 0.09$ & $0.3 \pm 0.09$ & 98 \\
\hline Cs & $\begin{array}{l}\text { 1632c (trace } \\
\text { elements in } \\
\text { coal) }\end{array}$ & $0.58 \pm 0.03$ & $0.59 \pm 0.01$ & 98 \\
\hline Th & $\begin{array}{l}2709 \text { (trace } \\
\text { elements in } \\
\text { soil) }\end{array}$ & $11.5 \pm 0.4$ & $11 \pm 3.3$ & 93 \\
\hline $\mathrm{U}$ & $\begin{array}{l}2709 \text { (trace } \\
\text { elements in } \\
\text { soil) }\end{array}$ & $2.7 \pm 0.2$ & $3 \pm 0.9$ & 110 \\
\hline
\end{tabular}

1 is the direct comparison of concentrations in soft tissues (wet weight basis) with seafood safety guidelines based on established maximum permissible limits (MPLs);

2 is the characterization of the amount of mussel meat (maximal provisional consumption rate MPCR, $\mathrm{kg} /$ week) that would need to be consumed per week by a 70-kg average adult to reach the provisional tolerable weekly intake (PTWI) established by the JECFA or related reference limits;

3 is the assessment of differences between estimated daily intakes (EDI) with RfD and calculation of risk quotient (RQ), which corresponded to the ratio between estimated weekly intakes (EWI) and prescribed PTWI values of the element;

4 is the estimation of target hazardous quotient (THQ) and total hazardous index (HI) which corresponded to the sum of all quotients from elements as its combinations for each station for the local coastal population

The key ratios and limits were used in the following specification:

The maximal permissible levels (MPL) were used for the determination of limits for food and were established by organizations such as the European Commission or United States Food and Drugs Administration. The MPLs for seafood were set for $\mathrm{Cr}, \mathrm{Mn}, \mathrm{Zn}$, As, Se; expressed in $\mu \mathrm{g} / \mathrm{g}$ of wet weight and characterized by upper levels of elementspecific concentrations in an object of the environment, which, during a year of human consumption, would not cause any adverse effects.

PTWI represents the permissible weekly exposure in humans as a result of the natural occurrence of a substance in food and drinking water. PTWI is used for food contaminants such as heavy metals that are characterized by cumulative properties. On any particular day, consumption of seafood containing above-average levels of the contaminant may exceed the proportionate share of its weekly tolerable intake. The assessment takes into account such daily variations, the primary concern being prolonged exposure to the contaminant because of its ability to accumulate within the body over a period of time. PTWI is a more representative ratio than TDI because the daily fluctuations in elemental contents are considered and accounted for.

Reference dose (RfD) is a daily oral exposure to the human population (including sensitive subgroups) that is likely to be without an appreciable risk of deleterious effects over a lifetime. The RfD can be derived from NOAEL or LOAEL, benchmark dose with uncertainty factors generally applied to reflect limitations of the data used.

MPCR $(\mathrm{kg})$ is the maximal permissible consumption rate, which can lead to exceeding the PTWI limit. This value was calculated as an average of all maximal individual concentrations obtained from all stations $(\mathrm{n}=92)$.

EWI ( $\mu \mathrm{g} / \mathrm{kg}$ bw/week) is the estimated weekly intake, which was calculated using the equation:

$E W I=\frac{C \cdot C R_{W}}{B W}$,

Where $\mathrm{C}$ - concentration of element $(\mu \mathrm{g} / \mathrm{g}) ; \mathrm{CR}_{\mathrm{W}}$ - weekly consumption rate (200 g/week in our study); BW - body weight.

Average BW (body weight, kg). For South Africa the average BW was calculated from the mean body mass index and height of men and women according to a national survey conducted in 2016 (NDoH, 2019). The mean weight of women aged $25+$ was $75.6 \mathrm{~kg}$ and for men aged $25+$, it was $71.8 \mathrm{~kg}$. Therefore, we used a nominal $70 \mathrm{~kg}$ as a representative mean value of weight among the whole adult population, including the 18-25 age group.

EDI ( $\mu \mathrm{g} / \mathrm{kg}$ bw/day) calculated similarly to EWI, by using daily consumption rate $(28.6 \mathrm{~g} /$ day $)$.

Risk quotient (RQ) was assessed as a ratio between estimated weekly intake (EWI) and provisional tolerable weekly intake (PTWI), which was presented by JECFA, 2019 (for several elements it was calculated on PMTDI). Risk quotients were assessed based on the adopted ratio from 
Stankovic et al., 2012. RQ $>1$ corresponded to a potential human health risk scenario in the case of consumption of mussels with average and maximum concentrations of the given element.

Target hazardous quotient (THQ), developed by USEPA (1989) fits well for the purposes of human health risk assessment for non-carcinogenic elements in the local human population over a lifetime in comparison with the reference oral dose (RfD). THQ was calculated using the equation (Yap et al., 2016):

$T H Q=\frac{E F \cdot E D \cdot C R \cdot C \cdot 10^{-3}}{R f D \cdot B W \cdot A T}$

Where $\mathrm{EF}$ is the exposure frequency (365 days); $\mathrm{ED}$ is exposure duration (average expectancy is 70 years); CR is consumption rate (28.6 g/day/ person), $\mathrm{C}$ is the concentration of element (wet weight basis), RfD is reference dose ( $\mu \mathrm{g} / \mathrm{kg}$ bw/day); BW is body weight (for South Africa the average weight was established as $70 \mathrm{~kg}$ ); AT is 30 years, an average exposure time for non-carcinogens (USEPA, 2011). THQ $>1$ reflects the high potential risk at human health via the consumption of mussels in constant dietary conditions over a lifetime.

HI (total hazard index) - represents as summarize values of THQs of $n$ elements for each station:

$H I=\sum_{i=1}^{n} T H Q_{i}$. Total hazard index HI $>1$ designates the hazard risk on human health for the local population based on multiple elements in mussel meat.

Risks were assessed for all determined elements to identify the potentially hazardous elements among those analyzed. Depending on the different approaches to assess the potential health risk of mussels' consumption for local coastal populations, different conclusions were suggested.

\section{Results}

\subsection{Group of microelements in mussels}

The ranges of concentrations and means of the determined elements in all stations are presented in Table 3. The PCA showed 4 basic groups of elements, which differ by their sources, way of entering the organisms, and suggested origin: terrigenous ( $\mathrm{Al}, \mathrm{S}, \mathrm{Cl}, \mathrm{K}, \mathrm{Ca}, \mathrm{Sc}, \mathrm{V}, \mathrm{Cr}, \mathrm{Mn}, \mathrm{Fe}$, $\mathrm{Co}, \mathrm{Ni}, \mathrm{Rb}, \mathrm{Sb}, \mathrm{Cs}$, Th), anthropogenic (Zn, As, Br, I, U), hydrogenous ( $\mathrm{Na}, \mathrm{Mg}, \mathrm{Cl}$ ), and biogenic (Ca, Sr). It was obtained that the mussels with high concentrations of the terrigenous group were at st. 8 (Durban), and anthropogenic group at st. 2 (Strandloper), st. 4 (Waterfront), and st. 5 (Hout Bay) with local differences.

Significant spatial differences between concentrations in mussels were found. The highest concentrations of Al, Sc, Ti, V, Cr, Mn, Fe, Co, Th, U were obtained at st. 8 (Durban), while $\mathrm{Zn}, \mathrm{As}$, and $\mathrm{Br}-$ at st. 4 (Hout Bay).

In studied mussels, the elements such as $\mathrm{Cr}, \mathrm{Zn}$, As and Se (which ranged $0.2-2.8,14-290,1.6-4.6$, and $0.31-2.4 \mathrm{ppm}$ of wet weight, respectively) exceeded the average maximum permissible levels for fish products in different countries, established by Nauen (1983); USFDA (1993, 2007), and DOH (2004).

\subsection{Comparison of the concentrations in soft tissues with maximum permissible levels for seafood products}

Compared to the reference data (based on raw mussels and in diet, in wet weight of mussels, high levels (by a factor of 2-4) of concentrations of $\mathrm{Al}, \mathrm{Cr}, \mathrm{Mn}, \mathrm{Fe}, \mathrm{Ni}, \mathrm{Zn}, \mathrm{Se}, \mathrm{Sb}$ were observed (Table 3 ), as well as equal levels of $\mathrm{V}$ and $\mathrm{Co}$, and low levels of As. For all considered elements (mean values), the majority of individuals were characterized by element concentrations lower than existing MPLs for Cr, Zn, As, and Se (regarding shellfish and other marine food, according to Nauen, 1983 and USFDA, 2007) (Fig. 2). The maximum content of $\mathrm{Cr}$ (2.8 ppm), As (4.6 ppm) and Se $(2.4 \mathrm{ppm})$ in mussel batches exceeded the average
Table 3

Ranges of individual concentrations among all stations in mussels and reference data (all data are presented on a wet weight basis).

\begin{tabular}{|c|c|c|c|c|c|}
\hline & \multirow{2}{*}{\multicolumn{2}{|c|}{$\begin{array}{l}\text { Ranges of individual } \\
\text { concentrations }(\mu \mathrm{g} / \mathrm{g}) \text {, } \\
n=92\end{array}$}} & \multicolumn{2}{|c|}{ Reference data $(\mu \mathrm{g} / \mathrm{g})$} & \multirow{3}{*}{$\begin{array}{l}\text { MPL } \\
(\mu g / g) \\
(c)\end{array}$} \\
\hline & & & \multirow{2}{*}{$\begin{array}{l}\text { raw mussels } \\
\text { Richir and Gobert, } \\
2014 \text { (a) }\end{array}$} & \multirow{2}{*}{$\begin{array}{l}\text { table shellfish } \\
\text { Leblanc et al., } \\
2005 \text { (b) }\end{array}$} & \\
\hline & $\min -\max$ & mean & & & \\
\hline $\mathrm{Na}$ & $6140-18900$ & 10,510 & & 5422 & \\
\hline $\mathrm{Mg}$ & $1020-4320$ & 2200 & & 509 & \\
\hline $\mathrm{Al}$ & $8-1090$ & 208 & $13-280$ & 17 & \\
\hline S & $2440-26000$ & 9500 & & & \\
\hline $\mathrm{Cl}$ & $10100-30400$ & 18220 & & & \\
\hline $\mathrm{K}$ & $930-4060$ & 2500 & & & \\
\hline $\mathrm{Ca}$ & $970-14100$ & 3550 & & 753 & \\
\hline Sc & $0.002-0.189$ & 0.035 & & & \\
\hline $\mathrm{V}$ & $0.1-4.2$ & 0.8 & $0.7-4.0$ & & \\
\hline $\mathrm{Cr}$ & $0.2-2.8$ & 0.8 & $0.06-0.69$ & 0.09 & 1 \\
\hline Mn & $0.3-29.9$ & 4.8 & $1.1-6.6$ & 2.7 & \\
\hline $\mathrm{Fe}$ & $16-570$ & 124 & $21-210$ & & \\
\hline Co & $0.04-0.46$ & 0.13 & $0.12-0.44$ & 0.05 & \\
\hline $\mathrm{Ni}$ & $0.06-1.69$ & 0.58 & $0.23-1.08$ & 0.23 & $(80)$ \\
\hline $\mathrm{Zn}$ & $14-290$ & 60 & $11-72$ & 66 & $\begin{array}{l}100 \\
(300)\end{array}$ \\
\hline As & $1.6-4.6$ & 2.6 & $5.4-14.7$ & 1.9 & $\begin{array}{l}1-5 \\
(86)\end{array}$ \\
\hline $\mathrm{Se}$ & $0.31-2.4$ & 0.74 & $0.48-1.38$ & 0.01 & $0.3-2$ \\
\hline $\mathrm{Br}$ & $44-220$ & 103 & & & \\
\hline $\mathrm{Rb}$ & $0.74-2.52$ & 1.17 & & & \\
\hline $\mathrm{Sr}$ & $9.2-86.4$ & 24.8 & & & \\
\hline $\mathrm{Sb}$ & $0.002-0.031$ & 0.009 & $0.002-0.009$ & 0.002 & \\
\hline I & $2-36$ & 11 & & & \\
\hline Cs & $0.003-0.082$ & 0.015 & & & \\
\hline Th & $0.002-0.450$ & 0.045 & & & \\
\hline $\mathrm{U}$ & $0.03-0.22$ & 0.09 & & & \\
\hline
\end{tabular}

For comparison, the concentrations from the present study and reference from Richir and Gobert, 2014 were converted from dry weight to wet weight by using our $\mathrm{CF}=0.32$. (a) Richir and Gobert, 2014. All mussels (Mytilus galloprovincialis) were collected from 1 sampling site at the east Corsica before spawning season; (b) Leblanc et al., 2005 - concentrations in table shellfish group (French Total Diet Study); (c) average data from Nauen, 1983; in brackets - data from USFDA, 1993, 2007; DOH, 2004.

MPLs established by different countries (from minimums to maximums of MPL), and amounted to 1,3 , and $1.2 \mathrm{ppm}$, respectively. The individuals with maximum concentrations at the st. 4, 5 (Waterfront, Hout Bay) reached the MPL for $\mathrm{Cr}$ and the whole local set from st. 8 (Durban) was above the limit. The limit for $\mathrm{Zn}$ in South Africa is set at the level of $300 \mu \mathrm{g} / \mathrm{g}$ ww (DOH, 1994) that is higher than the maximum value obtained in mussels $(290 \mu \mathrm{g} / \mathrm{g} w \mathrm{ww})$. Zn was at the highest level in individuals from st. 3 (Strandloper), 4 (Waterfront), and st. 5 (Hout Bay). Arsenic was below the maximum MPL of $5 \mu \mathrm{g} / \mathrm{g}$ at all stations, but higher than average MPL $(3 \mu \mathrm{g} / \mathrm{g})$ at st. $3,4,5$, and 8 . The concentrations of arsenic in the majority of individuals from st. 5 were above the average limit. The maximum concentrations of selenium were higher than the limit $(2 \mu \mathrm{g} / \mathrm{g})$ at stations 4 and 5 , but the means in these sets were lower than $1.5 \mu \mathrm{g} / \mathrm{g}$ ww.

\subsection{Estimated intakes of mussels and maximal permissible consumption}

The estimated consumption of mussels per week and per day was compared with the corresponding existing regulatory limits. For a convenient representation of the maximum potential intake of elements, we used the amount of mussel meat that must be eaten to exceed the reference limits.

The EWI for all studied elements were below the recommended PTWI (Table 4).

PTWI for total arsenic was determined by using the ratio of $42 \%$ inorganic/total for mussels based on the study by Chiesa et al. (2018) from the equation: $15 / 0.42=35.7 \mu \mathrm{g} / \mathrm{kg}$ bw/week, calculated using 

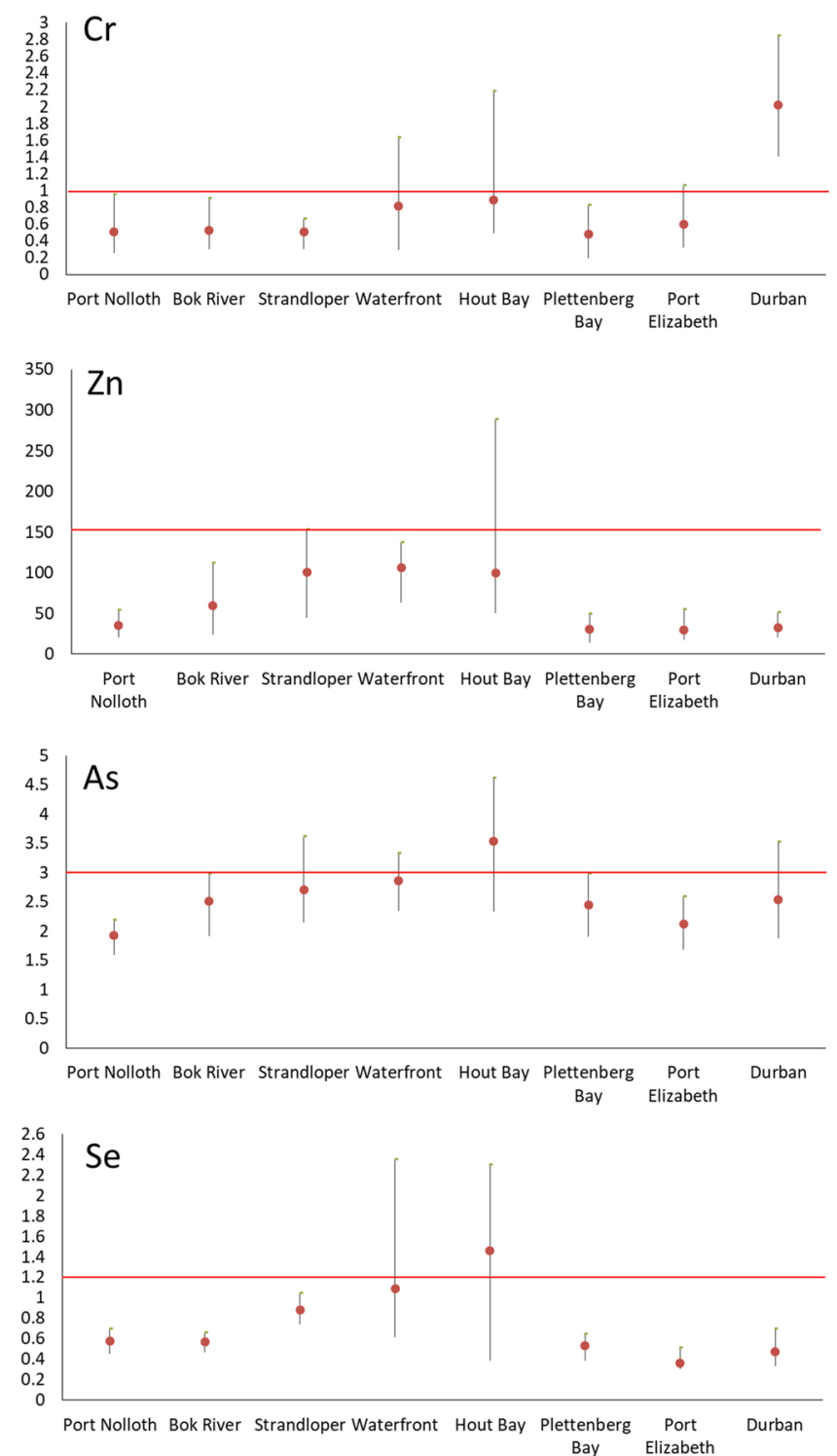

Fig. 2. Means, maximum and minimum concentrations (vertical bars) of $\mathrm{Cr}$, $\mathrm{Zn}$, and As (wet weight basis) in soft tissues of mussels along South African coastline. Red line corresponds to average MPLs.

the most current estimated PTWI (15 $\mu \mathrm{g} / \mathrm{kg}$ bw/week, JECFA, 2011).

MPCR (Table 4) reflected the maximum intake of mussel meat, which a person could eat per week without any health risk (below or at the level of prescribed or calculated PTWI). The MPCR in $\mathrm{kg} /$ week could be used for the regulation of potentially safe daily dishes in local coastal regions. For each determined element, the total consumption of mussel meat was normalized using the minimal values (in bold), and the maximum recommended weekly dietary intake was calculated as lower than 250-770 g (according to the MPCR for Al, Cr, As, and I at the maximal levels in all coastal stations) throughout life at worst. This corresponds to $36-111 \mathrm{~g} /$ day (10-20 individual mussels).

The MPCR for elements such as $\mathrm{Cl}$ and $\mathrm{Br}$ could not be assessed correctly without knowing the form of the element (chemical compound) in mussels. The reference limits for bromine were consistent with bromate, while the intakes were calculated for total bromine.

Our data revealed lower levels of MPCR $(\mathrm{kg})$ for $\mathrm{Zn}, \mathrm{Fe}$, As. An exception was the high amount of $\mathrm{Ni}(2.7-3.5)$ in comparison with data by Jovic et al., 2012 (7.1-21.7, 11.5-14.8, 3.6-8.6 respectively) on the amounts of mussel meat in $\mathrm{kg}$, which could be consumed by a $70 \mathrm{~kg}$ person per week, to exceed the limiting PTWI at the level of $\mathrm{CR}=125 \mathrm{~g}$
Table 4

Regulation limits for maximum consumptions of elements (total amounts) estimated for weekly and daily intakes and maximal permissible consumption rate.

\begin{tabular}{|c|c|c|c|c|c|c|}
\hline & PTWI & RfD & PMTDI & $\begin{array}{l}\mathrm{EWI}^{\mathrm{d}} \\
(\mu \mathrm{g} / \mathrm{kg} \\
\mathrm{bw} / \\
\text { week) }\end{array}$ & $\begin{array}{l}\mathrm{EDI}^{\mathrm{d}} \\
(\mu \mathrm{g} / \mathrm{kg} \\
\mathrm{bw} / \\
\text { day })\end{array}$ & $\begin{array}{l}\text { MPCR } \\
\text { (kg/ } \\
\text { week) }\end{array}$ \\
\hline & $\begin{array}{l}\mu \mathrm{g} / \mathrm{kg} \text { bw/ } \\
\text { week }\end{array}$ & $\begin{array}{l}\mu \mathrm{g} / \mathrm{kg} \text { bw/ } \\
\text { day }\end{array}$ & $\begin{array}{l}\mu \mathrm{g} / \mathrm{kg} \text { bw/ } \\
\text { day }\end{array}$ & & & \\
\hline $\mathrm{Na}$ & $\begin{array}{l}24500000 \\
\text { a }\end{array}$ & & 3500000 & 39600 & 5660 & 123 \\
\hline $\mathrm{Al}$ & 2000 & & & 1230 & 180 & 0.3 \\
\hline $\mathrm{Cl}$ & $1050^{\mathrm{a}}$ & $\begin{array}{l}100^{\mathrm{e}} \\
3\left(\mathrm{Cr}^{+6}\right)\end{array}$ & 150 & 68000 & 9740 & - \\
\hline $\mathrm{Cr}$ & $5-20^{b}$ & $\begin{array}{l}1500 \\
\left(\mathrm{Cr}^{+3}\right)\end{array}$ & 100 & 3.95 & 0.56 & $\begin{array}{l}\mathbf{0 . 2 5 -} \\
1.0\end{array}$ \\
\hline $\mathrm{Mn}$ & $980^{a}$ & 140 & & 24.2 & 3.5 & 8.1 \\
\hline $\mathrm{Fe}$ & $5600^{a}$ & $700^{f}$ & 800 & 630 & 90 & 1.8 \\
\hline Co & $700^{a}$ & $300^{f}$ & 100 & 0.53 & 0.08 & 265 \\
\hline $\mathrm{Ni}$ & 35 & 20 & 5 & 2.46 & 0.35 & 2.8 \\
\hline $\mathrm{Zn}$ & $\begin{array}{l}7000^{\mathrm{a}} \\
35.7^{\mathrm{a}}\end{array}$ & $\begin{array}{l}300 \\
0.71\end{array}$ & $300-1000$ & 320 & 46 & 4.4 \\
\hline As & $\begin{array}{l}15 \\
\text { (inorganic) }\end{array}$ & $\begin{array}{l}0.3 \\
\text { (inorganic) }\end{array}$ & & 9.22 & 1.32 & 0.77 \\
\hline Se & $35^{c}$ & 5 & 0.3 & 3.18 & 0.45 & 2.2 \\
\hline $\mathrm{Br}$ & - & $\begin{array}{l}4 \\
\text { (bromate) }\end{array}$ & & 390 & 56 & - \\
\hline $\mathrm{Sr}$ & $4200^{c}$ & 600 & & 140 & 20 & 6.1 \\
\hline $\mathrm{Sb}$ & $2.8^{c}$ & 0.4 & 0.36 & 0.042 & 0.006 & 13.2 \\
\hline I & $119^{\mathrm{a}}$ & & 17 & 49 & 7 & 0.49 \\
\hline $\mathrm{U}$ & $21^{c}$ & $\begin{array}{l}3 \text { (soluble } \\
\text { salts) }\end{array}$ & & 0.42 & 0.06 & 10.1 \\
\hline
\end{tabular}

a Calculated from PMTDI (data from 87th JECFA database - June 2019).

b Used in Tam and Mok (1991). Calculation based on recommended dietary allowances (0.05-0.2 mg/day) and the body weight $70 \mathrm{~kg}$ (Lin et al., 2004).

c Calculated from RfD (data from IRIS EPA, 2019).

d Average values of maximum intakes from each station (per week and per day).

e Chlorine RfD was not relevant as the total amount of chlorine and corresponded to the pure compound.

${ }^{\mathrm{f}}$ For RfDs for $\mathrm{Fe}$ and Co were used subchronic and chronic LOAEL respectively.

mussels/person/week. The lower values can be explained by higher maximum concentrations of elements in our study and higher consumption rate ( $\mathrm{CR}=200 \mathrm{~g} /$ person/week). Also, Jovic et al. (2012) used PTWI $350 \mu \mathrm{g} / \mathrm{kg}$ bw/week for total arsenic referencing Whyte et al., (2009). In our case, the diminished MPCR was calculated using a lower level of PTWI (35.7 $\mu \mathrm{g} / \mathrm{kg}$ bw/week) corresponding to total As.

\subsection{Risk quotients based on estimated intakes}

The EDIs ( $\mu \mathrm{g} / \mathrm{kg}$ bw/day) of all elements were lower than RfDs except for $\mathrm{Br}$ and As (Table 5), which were presented as informative. Instead of the RfD for the total bromine was presented the existing RfD for bromate. In the case of arsenic, we could use the RfD for the inorganic form that corresponded for total As to $0.3 / 0.42=0.71 \mu \mathrm{g} / \mathrm{kg}$ bw/ day (based on $42 \%$ inorganic/total As according to Chiesa et al., 2018), which is higher than each of our EDI levels at the stations. These elements are included in anthropogenic factors and cause increasing potential risks in mussel consumption.

\subsection{Risk}

Quotients for the majority of elements, which were calculated for ranges from minimum and maximum concentrations in mussels from each station, were less than 1.0 (Fig. 3). The exceptions were the maximums of Cr at st. 4 (Waterfront), st. 5 (Hout Bay), and the major part of the batch from st. 8 (Durban) revealed high values of RQ for Cr. Also, the maximum values of $\mathrm{RQ}$ for $\mathrm{Al}$ at the Durban station (8) were higher than 
Table 5

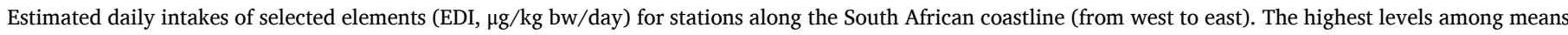
and maxima are given in bold.

\begin{tabular}{|c|c|c|c|c|c|c|c|c|c|c|c|c|c|}
\hline & & $\mathrm{Cr}$ & $\mathrm{Mn}$ & $\mathrm{Fe}$ & Co & $\mathrm{Ni}$ & $\mathrm{Zn}$ & As & $\mathrm{Se}$ & $\mathrm{Br}$ & $\mathrm{Sr}$ & $\mathrm{Sb}$ & $\mathrm{U}$ \\
\hline \multirow{2}{*}{1} & mean & 0.2 & 0.9 & 36 & 0.06 & 0.2 & 15 & 0.8 & 0.24 & 41 & 8 & 0.003 & 0.04 \\
\hline & $\max$ & 0.4 & 1.5 & 51 & 0.09 & 0.3 & 22 & 0.9 & 0.28 & 48 & 12 & 0.005 & 0.06 \\
\hline \multirow{2}{*}{2} & mean & 0.2 & 0.3 & 24 & 0.02 & 0.1 & 24 & 1.0 & 0.23 & 37 & 11 & 0.001 & 0.05 \\
\hline & $\max$ & 0.4 & 0.7 & 35 & 0.03 & 0.1 & 46 & 1.2 & 0.27 & 45 & 17 & 0.002 & 0.08 \\
\hline \multirow{2}{*}{3} & mean & 0.2 & 0.5 & 24 & 0.03 & 0.2 & 41 & 1.1 & 0.36 & 46 & 13 & 0.002 & 0.05 \\
\hline & $\max$ & 0.3 & 0.7 & 34 & 0.03 & 0.2 & 63 & 1.5 & 0.43 & 61 & 30 & 0.004 & 0.06 \\
\hline \multirow{2}{*}{4} & mean & 0.3 & 1.3 & 55 & 0.05 & 0.3 & 43 & 1.2 & 0.44 & 41 & 9 & 0.008 & 0.03 \\
\hline & $\max$ & 0.7 & 2.2 & 173 & 0.09 & 0.4 & 56 & 1.4 & 0.96 & 59 & 13 & 0.013 & 0.05 \\
\hline \multirow{2}{*}{5} & mean & 0.4 & 0.9 & 25 & 0.03 & 0.2 & 41 & 1.4 & 0.6 & 63 & 8 & 0.005 & 0.05 \\
\hline & $\max$ & 0.9 & 1.8 & 52 & 0.05 & 0.3 & 118 & 1.9 & 0.94 & 90 & 13 & 0.009 & 0.09 \\
\hline \multirow{2}{*}{6} & mean & 0.2 & 1.3 & 19 & 0.03 & 0.1 & 12 & 1.0 & 0.22 & 30 & 8 & 0.002 & 0.02 \\
\hline & $\max$ & 0.3 & 2.1 & 62 & 0.04 & 0.1 & 20 & 1.2 & 0.26 & 39 & 21 & 0.004 & 0.04 \\
\hline \multirow{2}{*}{7} & mean & 0.2 & 3.5 & 50 & 0.06 & 0.4 & 12 & 0.9 & 0.15 & 38 & 11 & 0.003 & 0.03 \\
\hline & $\max$ & 0.4 & 6.3 & 82 & 0.08 & 0.7 & 22 & 1.1 & 0.21 & 51 & 15 & 0.004 & 0.04 \\
\hline \multirow{2}{*}{8} & mean & 0.8 & 6.7 & 162 & 0.13 & 0.4 & 13 & 1.0 & 0.19 & 42 & 13 & 0.006 & 0.03 \\
\hline & $\max$ & 1.2 & 12.2 & 233 & 0.19 & 0.7 & 21 & 1.4 & 0.28 & 56 & 35 & 0.008 & 0.05 \\
\hline \multicolumn{2}{|c|}{ Oral RfD ( $\mu \mathrm{g} / \mathrm{kg}$ bw/day) } & $30^{\mathrm{a}}$ & 140 & $700^{\mathrm{b}}$ & $0.3^{\mathrm{b}}$ & $20^{c}$ & 300 & $0.7^{\mathrm{d}}$ & 5 & $4^{e}$ & 600 & 0.4 & $3^{f}$ \\
\hline
\end{tabular}

a Calculated from RfD for $\mathrm{Cr}^{+6}-3 \mu \mathrm{g} / \mathrm{kg}$ bw/day.

b Calculated from subchronic LOAEL (Fe) and chronic LOAEL (Co).

c For soluble salts.

${ }^{\mathrm{d}}$ RfD for total As, calculated as $0.7=0.3 / 0.42$ from RfD for inorganic As.

e RfD for bromate.

${ }^{\mathrm{f}}$ For soluble salts.

1 and close at the Waterfront station (4).

The low-risk levels are attributed to the low intake of elements through the mussel meat in accordance with the prescribed PTWI and the established average intake of $200 \mathrm{~g}$ /week per person.

Aluminium reached the highest level of $R Q=1.2$ at the Durban (st. 8) (higher at st. 8 than at st. 2, 3, 5, 6; Kruskal-Wallis test, p $<0.0002$ ), while arsenic RQ amounted to 0.9 at the Hout Bay (higher at st. 5 than in mussels from st. 1, 7, 8; Kruskal-Wallis test, $\mathrm{p}<0.03$ ). Other elements had the RQ levels less than 0.5. In general, this corresponds to an unlikely potential risk for human health via consumption of local mussels.

\subsection{Target hazardous quotients and total hazard index}

The maximum values (among maxima, Table 6) of HI were found for mussels from Hout Bay (Cape Town region) and Durban (in bold), which correlated well with the other approaches of risk evaluation (e.g. RQs for $\mathrm{Fe}$ ). Low values (among all data) for HI were found at the Bok river (Saldanha Bay), Plettenberg Bay, and Port Elizabeth.

The elements As and $\mathrm{Br}$ were excluded from the contribution to $\mathrm{HI}$ (Table 6) due to the specificity of RfD, but their calculated values were in the range of 0.9-2.2 and 7.8-19.2, respectively. Iodine, with a PMTDI value of $17 \mu \mathrm{g} / \mathrm{kg}$ day was adopted for the calculation of RfD, made maximum contributions in total $\mathrm{HI}$ for all stations, except st. 6 (Plettenberg Bay) and st. 7 (Port Elizabeth).

The elements $\mathrm{Mn}, \mathrm{Fe}, \mathrm{Co}, \mathrm{Ni}, \mathrm{Se}, \mathrm{Sr}, \mathrm{Sb}$, and $\mathrm{U}$ did not exceed 0.2 of THQ at any site. Levels of $\mathrm{Cr}, \mathrm{Co}, \mathrm{Zn}$, I were in some cases higher than 0.2 and could contribute to the total hazardous index. In the case of iodine, the high THQs were provided by low RfD, which were calculated on PMTDI due to the absence of an official level of RfD by EPA. It is interesting to note the high level of THQ for iodine at the West Coast stations $(1-5)$, which could be explained by the high hydrochemical levels in the surrounding waters, should be investigated in the future.

\section{Discussion}

\subsection{Elements with high risks in the studied sites}

All elements could be classified as potentially safe and hazardous based on the risk assessment by ratios of RQ, THQ, and HI and by accounting for their MPL and EWI.
According to the PCA results, the elements $\mathrm{Al}, \mathrm{Cr}$, and Ni corresponded to a terrigenous component present in the soft tissue of mussels. According to our data, Fe was associated with this group as well. Such elements could be accumulated in mussels via suspended mineral particles and could be ingested by humans. Al, considered as a non-volatile element, could be used as a marker for a terrigenous origin. The highest levels of Al intake (calculated on a wet weight basis) were found in the samples from Durban, Port Elizabeth, Waterfront, and Port Nolloth. Zn and As could be markers of an anthropogenic component in the mussel tissues and the maximum concentrations were determined in samples from the Hout Bay and Strandloper. The mean concentrations of $\mathrm{Al}, \mathrm{Cr}$, $\mathrm{Ni}, \mathrm{Zn}, \mathrm{As}$, and I among all individuals were $208,0.8,0.58,60,2.6$, and $11 \mathrm{ppm}$ of wet weight, respectively.

Cantillo (1998) showed that $\mathrm{Zn}$ concentrations above $200 \mathrm{ppm}$ are indicative of contamination. According to the literature data, the amount of inorganic As in mussels can vary from 1 to $50 \%$ (Feldmann and Krupp, 2011). Sloth and Julshamn (2008) found that inorganic As amounts to $42 \%$ of the total content. However, since 2011, the PTWI value of 15 has been rejected and a new one has not been introduced (Chiesa et al., 2018). Therefore, the MPCR, RQ, THQ, and HI calculated for As could be considered informative.

The EFSA Panel on Contaminants in the Food Chain decided to consider all reported analytical results in food as $\mathrm{Cr}^{+3}$ (EFSA, 2014). There is a lack of data on the presence of $\mathrm{Cr}^{+6}$ in food. Several studies have concluded that the percentage of $\mathrm{Cr}^{+6}$ relative to total $\mathrm{Cr}$ content in certain types of food is, on average, below $10 \%$ (in the range of $1.31-12.9 \%)$. However, it was also considered that all $\mathrm{Cr}^{+6}$ would turn into $\mathrm{Cr}^{+3}$ due to thermodynamic reactions varying from very fast (disappearance of $\mathrm{Cr}^{+6}$ in few minutes) to quite slow, with a partial survival of $\mathrm{Cr}^{+6}$ species for hours (EFSA, 2014).

In the case of $10 \%$ of $\mathrm{Cr}^{+6}$ from the total content, the RfD for total chromium could be determined as $3 / 0.1=30 \mu \mathrm{g} / \mathrm{kg}$ bw/day (data by EPA's IRIS). This value is higher than EDI $(0.56 \mu \mathrm{g} / \mathrm{kg}$ bw/day). The total RfD for chromium could be calculated on $90 \% \mathrm{Cr}^{+3}$ as 1500 / $90=1670 \mu \mathrm{g} / \mathrm{kg}$ bw/day, which is much higher than the total RfD calculated on $\mathrm{Cr}^{+6}$.

\subsubsection{Safe}

The levels of $\mathrm{Na}, \mathrm{Mn}, \mathrm{Fe}, \mathrm{Ni}, \mathrm{Sr}, \mathrm{Sb}$, and $\mathrm{U}$ in mussels could be considered relatively safe for consumption according to the hazardous 

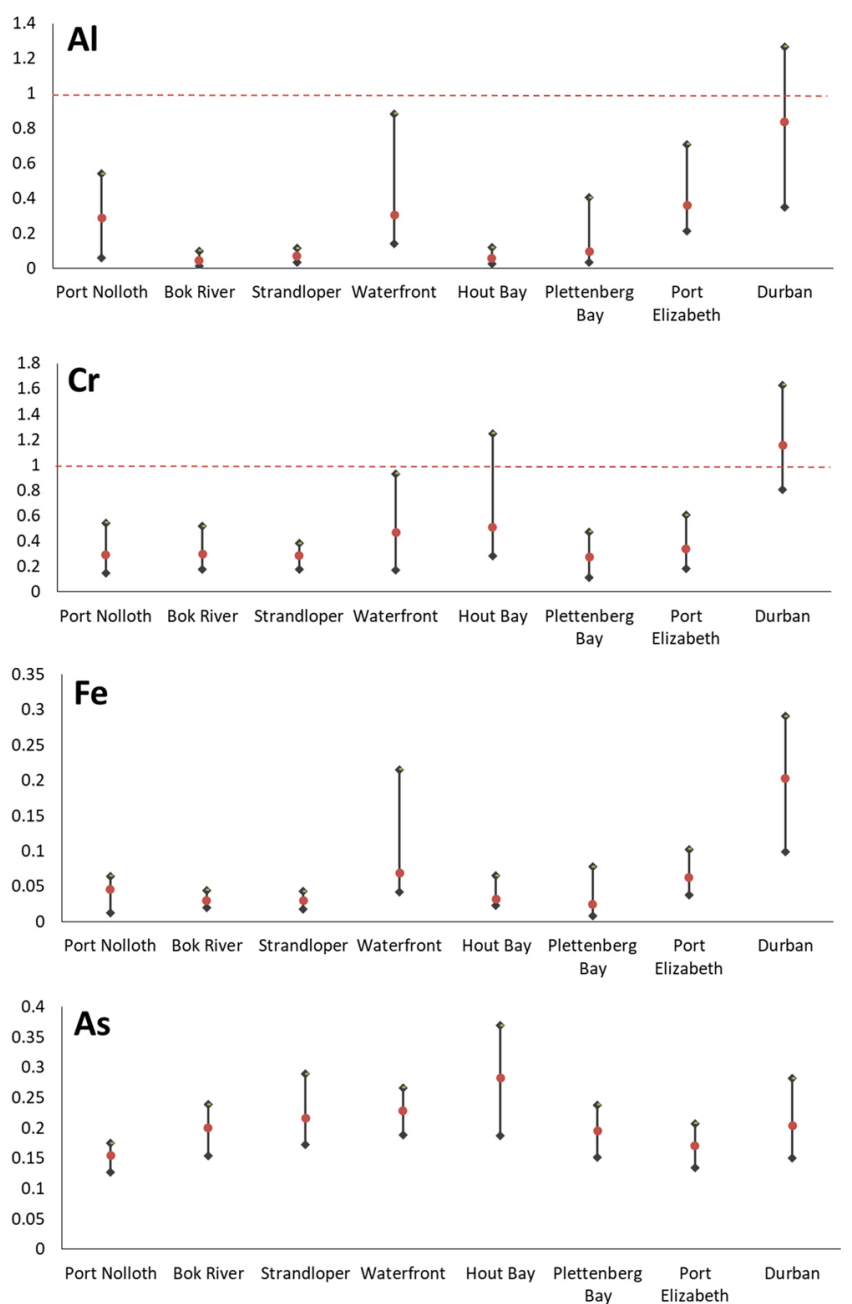

Fig. 3. Risk quotients for the best case, median case, and worst-case scenarios for $\mathrm{Al}, \mathrm{Cr}, \mathrm{Fe}$, and As in consumption of mussel tissues (wet weight basis) based on the provisional tolerable weekly intake (PTWI). Red line corresponded to 1.0 of RQ.

quotients and indexes. To exceed the tolerable limits (PTWI) for such elements, the person would have to ingest more than $1.8 \mathrm{~kg}$ mussel meat every week. Elements such as $\mathrm{Na}$ are usually associated with marine water chemical composition. $\mathrm{Mn}, \mathrm{Fe}, \mathrm{Ni}, \mathrm{Sr}, \mathrm{Sb}$, and $\mathrm{U}$ are usually associated with a terrigenous component (from weathering of rocks, f.e.) of suspended natural materials (sediments), but can increase due to anthropogenic pollution runoff. Differences in the concentrations of such elements between coastal zones are explained by local geological features and are reflected in the biochemistry of mussels.

It is important to note that in the coastal waters with intense runoff and sediment flows, the safe elements could be associated with the terrigenous group and create high risks due to pollution influence.

\subsubsection{Hazardous}

$\mathrm{Al}, \mathrm{Cr}, \mathrm{Co}, \mathrm{Zn}, \mathrm{As}$, Se, and I can increase the health risk if mussel meat is consumed more than $300 \mathrm{~g} /$ week per person and in the case of higher than individual maximum concentrations in mussel meat in accordance with the following ratios:

MPL: the maximum concentrations of $\mathrm{Cr}, \mathrm{Zn}$, As, and Se can exceed permissible levels set for seafood products. The mussels were adapted to these levels in the environment, but it could be the result of local coastal pollution (e.g. at the st. 5), which was confirmed by other indexes (the highest RQ, and THQ of $\mathrm{Zn}$ at the same station).

MPCR: the high amounts of $\mathrm{Al}, \mathrm{Cr}$, As, and I in mussels revealed that maximum consumption of mussels should be lower than $250 \mathrm{~g}$ per person per week to avoid potential dietary risks.

THQs in the range of $0.3-0.7$ for the elements $\mathrm{Cr}$, Co, Zn, and I contributed maximums in local $\mathrm{HI}$ (st. 1, 4, 5, and 8).

$\mathrm{Al}, \mathrm{Cr}$, and $\mathrm{Co}$ are associated with the terrigenous component but can be accumulated by mussels due to human activities at the harbors (described further). $\mathrm{Zn}$ and I play an essential role in the organisms in optimal amounts, but at the high concentrations determined in mussels, they could cause risks for human health. Since total concentrations of $\mathrm{Cr}$ and As exceeded MPLs they were considered as hazardous elements.

\subsection{Brief characteristics of hazardous elements and their input into the mussel environment}

\subsubsection{Aluminum}

Aluminum is a major component of the earth's crust. It is released to the environment both by natural processes and from anthropogenic sources, whereby natural processes far outweigh the contribution of anthropogenic sources. Aluminum is highly concentrated in soil-derived dust from natural processes, coal combustion, and activities as mining and agriculture that could be transported to marine sediments by coastal runoff. Usually, this element is connected with the terrigenous component and it is important to assess the possible risks for human health in the consumption of indigenous mussels from selected populated coastal

Table 6

Target hazardous quotients of several elements and hazard indexes among studied stations.

\begin{tabular}{|c|c|c|c|c|c|c|c|c|c|c|c|c|}
\hline & & $\mathrm{Mn}$ & $\mathrm{Fe}$ & Co & $\mathrm{Ni}$ & $\mathrm{Zn}$ & $\mathrm{Se}$ & $\mathrm{Sr}$ & $\mathrm{Sb}$ & I & $\mathrm{U}$ & HI \\
\hline \multirow{2}{*}{1} & mean & 0.005 & 0.04 & 0.17 & 0.004 & 0.04 & 0.04 & 0.01 & 0.006 & 0.29 & 0.011 & 0.63 \\
\hline & $\max$ & 0.009 & 0.06 & 0.25 & 0.006 & 0.06 & 0.05 & 0.02 & 0.01 & 0.74 & 0.017 & 1.23 \\
\hline \multirow{2}{*}{2} & mean & 0.002 & 0.03 & 0.07 & 0.003 & 0.07 & 0.04 & 0.02 & 0.003 & 0.18 & 0.013 & 0.43 \\
\hline & $\max$ & 0.004 & 0.04 & 0.09 & 0.003 & 0.13 & 0.05 & 0.02 & 0.005 & 0.27 & 0.023 & 0.65 \\
\hline \multirow{2}{*}{3} & mean & 0.003 & 0.03 & 0.07 & 0.003 & 0.12 & 0.06 & 0.02 & 0.005 & 0.31 & 0.014 & 0.64 \\
\hline & $\max$ & 0.004 & 0.04 & 0.08 & 0.004 & 0.18 & 0.07 & 0.04 & 0.008 & 0.43 & 0.017 & 0.89 \\
\hline \multirow{2}{*}{4} & mean & 0.008 & 0.07 & 0.14 & 0.006 & 0.12 & 0.08 & 0.01 & 0.016 & 0.17 & 0.009 & 0.64 \\
\hline & $\max$ & 0.014 & 0.21 & 0.26 & 0.009 & 0.16 & 0.16 & 0.02 & 0.027 & 0.2 & 0.014 & 1.09 \\
\hline \multirow{2}{*}{5} & mean & 0.005 & 0.03 & 0.09 & 0.005 & 0.12 & 0.1 & 0.01 & 0.012 & 0.39 & 0.015 & 0.79 \\
\hline & $\max$ & 0.011 & 0.06 & 0.15 & 0.007 & 0.33 & 0.16 & 0.02 & 0.02 & 0.61 & 0.026 & 1.43 \\
\hline \multirow{2}{*}{6} & mean & 0.008 & 0.02 & 0.09 & 0.001 & 0.04 & 0.04 & 0.01 & 0.004 & 0.07 & 0.005 & 0.29 \\
\hline & $\max$ & 0.013 & 0.08 & 0.11 & 0.002 & 0.06 & 0.04 & 0.03 & 0.009 & 0.09 & 0.012 & 0.45 \\
\hline \multirow{2}{*}{7} & mean & 0.021 & 0.06 & 0.17 & 0.009 & 0.03 & 0.03 & 0.02 & 0.006 & 0.15 & 0.007 & 0.51 \\
\hline & $\max$ & 0.039 & 0.1 & 0.24 & 0.015 & 0.06 & 0.04 & 0.02 & 0.007 & 0.2 & 0.013 & 0.74 \\
\hline \multirow{2}{*}{8} & mean & 0.041 & 0.2 & 0.38 & 0.008 & 0.04 & 0.03 & 0.02 & 0.013 & 0.19 & 0.01 & 0.95 \\
\hline & $\max$ & 0.074 & 0.28 & 0.53 & 0.014 & 0.06 & 0.05 & 0.05 & 0.018 & 0.26 & 0.013 & 1.39 \\
\hline KW & $\mathrm{P}<$ & 0.05 & 0.02 & 0.001 & 0.001 & 0.01 & 0.01 & 0.008 & 0.03 & 0.002 & 0.02 & \\
\hline
\end{tabular}

The values with the highest contribution (THQ $>0.2$ ) marked in bold.

The last case represents the significance values (p) among stations in the Kruskal-Wallis non-parametric test. 
zones.

The PTWI of Al established by JECFA at of $2 \mathrm{mg} / \mathrm{kg}$ bw/week, but the maximum estimated weekly intake reached $60 \%$ of this value according to our study. JECFA concluded that aluminium compounds could negatively affect the reproductive system and developing nervous system in rats, mice, dogs at $1 \mathrm{mg} / \mathrm{kg}$ bw of PMTDI (JECFA, 2011). In rats were noticed renal damage (hydronephrosis, urethral dilatation, obstruction, and/or presence of calculi) and reduced grip strength, but not cognitive impairment in the pups at the levels higher than the NOAEL of $30 \mathrm{mg} / \mathrm{kg}$ bw per day (JECFA, 2011). The levels of $\mathrm{Al}$ in mussels were in the range of $8-1088$ (mean 209) $\mu \mathrm{g} / \mathrm{kg}$ ww. The highest concentrations of aluminum were found for mussels from st. 8 (Durban), st. 4 (Waterfront).

\subsubsection{Chromium}

Chromium is associated with occupational exposures via numerous materials and processes, including chrome plating baths, colors and dyes, cement, tanning agents, wood preservatives, anticorrosive agents, welding fumes, lubricating oils and greases, cleaning materials, and textiles and furs.

While $\mathrm{Cr}^{3+}$ is a natural dietary constituent present in a variety of foods and also in dietary supplements, $\mathrm{Cr}^{+6}$ most commonly occurs in industrial processes and is present in drinking water usually as a consequence of anthropogenic contamination (EFSA, 2014). In humans, the dietary exposure levels of chromium absorption are relatively low $(<$ $10 \%$ of the ingested dose) and depend on its valence state and ligands. Most of the ingested $\mathrm{Cr}^{+6}$ is considered to be reduced in the stomach to $\mathrm{Cr}^{+3}$, which is poorly bioavailable and presents low ability to enter cells (EFSA, 2014).

Chromium is suggested to be an essential trace element for humans, as it is involved in the metabolism of carbohydrates and lipids (Gu et al., 2016). Suboptimal dietary intakes of $\mathrm{Cr}$ are associated with increased risks of cardiovascular diseases and diabetes (Kobla and Volpe, 2000). The Codex Alimentarius commissions of Australia, Japan, New Zealand, Taiwan, and the United States have not set regulatory limits for $\mathrm{Cr}$ in foods. The Chinese national standard maximum $\mathrm{Cr}$ concentration in seafood is $2.0 \mu \mathrm{g} / \mathrm{g}$ ww (MPHC, 2012) (Gu et al., 2016). The levels of chromium in the soft tissue of mussels were in the range of $0.2-2.8$ (mean 0.8) $\mu \mathrm{g} / \mathrm{kg}$ ww. It means that some individuals from st. 5 and 8 (Durban) contained higher amounts of this element than recommended by national standards.

\subsubsection{Cobalt}

Anthropogenic emissions of cobalt into the aquatic environment include cobalt mining and processing activities, the production of alloys and chemicals, sewage effluents, urban run-off, and agricultural run-off (Nagpal, 2004). The principal pathway involves the binding of cobalt to suspended solids, which settle to the bottom of the water body and become part of the bed sediments (Nagpal, 2004). The mussels could intake the cobalt in solid particles from resuspended bottom sediments.

Oral exposure may potentially entail many adverse effects in humans (cardiac effects, effects on erythropoiesis, effects on the thyroid, developmental effects, and allergic dermatitis). Cobalt has been found to be a sensitizer in humans. A daily oral intake of $600 \mathrm{~g}$ cobalt (based on a LOAEL of $1 \mathrm{mg} / \mathrm{kg}$ for polycythaemia) appears minimum risk level for humans that would protect from the known threshold-related adverse effects (EFSA, 2009). The oral cobalt dose of $0.54 \mathrm{mg}$ cobalt $/ \mathrm{kg}$-day represents a NOAEL for thyroid effects in humans. The point of departure of $1 \mathrm{mg}$ cobalt/kg-day for decreased iodine uptake in human thyroid is the LOAEL, dividing this point of departure by a composite uncertainty (UF) of 300 yields a subchronic p-RfD of $0.003 \mathrm{mg} / \mathrm{kg}$-day (USEPA, 2008). In our study the concentrations of cobalt in mussels were in the range of $0.04-0.46 \mu \mathrm{g} / \mathrm{kg}$ ww (mean 0.13 ) and maxima were noticed for st. 1 (Port Nolloth), st. 2 (Bok river), and st. 8 (Durban).

\subsubsection{Zinc}

Zinc is a ubiquitous metal present in the environment, as most rocks and many minerals contain zinc, which can be used for the zinc industry. Zinc is utilized as a protective coating of other metals, dye casting, construction industry, for alloys, dry cell batteries, dental, medical, and household applications, fungicide, topical antibiotics, and lubricants. Natural emissions results from erosion and forest fires.

Zinc is an essential trace element; the requirement for zinc changes throughout life and the health effects associated with zinc deficiency are numerous. Zinc occurs as a natural constituent in all plant and animal tissues and functions as an integral part of several enzyme systems. Protein foods are important dietary sources of zinc. The natural levels of this element are the highest in oysters, but in other seafood are lower. It was estimated that the average daily intake of zinc should not exceed $20 \mathrm{mg}$ /day for adults, otherwise cause harmful effects could occur. Oral $\mathrm{RfD}$ of $\mathrm{Zn}$ in $300 \mu \mathrm{g} / \mathrm{kg} /$ day set as NOAEL (USEPA, 2005). According to our studies, the estimated daily intake of zinc ranged from 12 (mean from station 6) to $43 \mu \mathrm{g} / \mathrm{kg}$ bw/day (maximum at individuals from station 4).

\subsubsection{Arsenic}

The high levels of arsenic in air, soils could be associated with pesticides, manure, and mining and smelting activities. Groundwater contains higher levels of arsenic due to thermal activity or the dissolution of arsenic minerals (Chakrabarty, 2015). Arsenic enters into organisms mainly through water and food. Fish and meat are the main sources of arsenic among food, but the percentage of inorganic arsenic is low. Oral $\mathrm{RfD}$ for As is $0.3 \mu \mathrm{g} / \mathrm{kg} /$ day above which dermatitis, lowered neuron transmission, and liver carcinoma may develop (Korkmaz et al., 2017). In our study, the estimated daily intakes of arsenic in consumption of mussels' meat is ranged from 0.9 (st. 1 - Port Nolloth) to $1.9 \mu \mathrm{g} / \mathrm{kg}$ bw/day (maximum in individuals from st. 5 - Hout Bay).

The maximum permitted arsenic concentrations in marine crustaceans, fish, and shellfish are $0.5,0.1$, and $0.5 \mu \mathrm{g} / \mathrm{g}$ ww, according to the Chinese Food Codex (MPHC, 2012). The United States Food and Drug Administration and the WHO have specified a permissible As the concentration of $0.5 \mu \mathrm{g} / \mathrm{g} \mathrm{ww}$, and a comparable permissible concentration (specified in EC regulation 466/2001 and amended in EC regulation $221 / 2002$ ) is used in the European Union (Gu et al., 2016).

Arsenic is often found at high concentrations in organic forms (Shiomi, 1994), especially in the marine environment up to $50 \mu \mathrm{g} / \mathrm{g}$ of arsenic on a wet weight basis in some seafood including seaweed, fish, shellfish, and crustaceans. The percentages of inorganic As in seafood are 1-5\% Munoz et al. (1999), while in bivalve molluscs, they are $1.9-6.5 \%$. Mussels usually contain approximately 1-2 \% of inorganic As compounds (Sloth and Julshamn, 2008) but with high and potentially toxic levels of As, this percentage could increase to $50 \%$ (Feldmann and Krupp, 2011; Chiesa et al., 2018). Arsenobetaine, which is the principal arsenic form in fish and crustaceans is considered non-toxic. Inorganic arsenic is usually classified as a human carcinogen. The intake of total arsenic in the human diet is dominated by organic arsenic derived from seafood (Gu et al., 2016).

\subsubsection{Iodine}

Iodine is an essential element for animals and humans because it is a key component in the thyroid hormones thyroxine and triiodothyronine. Deficiency can lead to many diseases, ranging from enlargement of the thyroid to severe cretinism with mental retardation (Goldhaber, 2003).

High consumption of iodine by humans can lead to goiter, hypothyroidism, or hyperthyroidism (Leung and Braverman, 2012). (Goldhaber, 2003) noticed that at levels of $200-500 \mathrm{mg} / \mathrm{kg}$-day, the acute toxicity of iodine to animals resulted in death, and consumption of higher than $10 \mathrm{mg}$ per day was toxic to some humans. EPA has not set an $\mathrm{RfD}$ for iodine. An upper level of $1.1 \mathrm{mg} /$ day was set based upon thyroid dysfunction as a critical endpoint whereas the nutritional requirement for iodine (under review by WHO) is currently considered to be in the 
range of 0.10 to $0.14 \mathrm{mg}$ per person per day. A LOAEL of $1.7 \mathrm{mg} / \mathrm{day}$ was selected based on two studies that reported elevated thyroid-stimulating hormone concentrations in men receiving iodine supplements. WHO had set a PMTDI for iodine of $1 \mathrm{mg}$ /day (corresponding to $0.017 \mathrm{mg} / \mathrm{kg}$ bw) (JECFA, 2019). This was based on the observation that an iodine intake of $1 \mathrm{mg}$ / day or less is probably safe for the majority of the population, but may cause adverse effects for some individuals, e.g., people with thyroid disorders or those that are particularly sensitive to iodine (Goldhaber, 2003).

The concentrations of iodine in wet mussels ranged from 2.4 (minimum at st. 6 - Plettenberg Bay) to 36.2 (at st. 1 - Port Nolloth).

\subsection{Regions with high risks according to risk quotients}

According to the estimated consumption of mussel meat and the evaluated MPL, RQ, and THQ (HI) for the elements $\mathrm{Cr}, \mathrm{Fe}, \mathrm{Co}, \mathrm{Zn}$, and I, the riskiest zones (HI $>1$ ) were st. 1 (Port Nolloth), st. 4 (Waterfront), st. 5 (Hout Bay) and st. 8 (Durban). St. 1 (Port Nolloth) revealed risks $(\mathrm{HI}>1)$ based on the levels of iodine consumption due to the high concentration of this element and low values for the calculated limits (RfD and PTWI). It is interesting to note the high levels of THQ for iodine at the West Coast stations (1-5), which can be explained by the high hydrochemical levels in the surrounding waters, which should be investigated in the future.

The calculated ratios revealed the specificities of pollution on the West Coast (st. 4, 5 - Cape Town water area) and on the East Coast (st. 8 - Durban). The high concentrations of the elements Al, Sc, Ti, V, Cr, Mn, $\mathrm{Fe}, \mathrm{Co}$, Th, $\mathrm{U}$ in mussels which might be of terrigenous origin collected from the East Coast could be associated with the climatic features of the subtropical zone. (Erasmus et al., 2020) found that Fe, Co, Ni, Zn, and As in four species of marine organisms (including mussels) were higher at a subtropical site (Sheffield Beach) than at a warm temperate site (Tsitsikamma). The authors explained this by diffuse sources of metal input through estuaries and groundwater seepage into the marine environment. The $\mathrm{Ti}, \mathrm{Cr}$, and $\mathrm{Cd}$ were higher at Tsitsikamma and this was attributed to the metal-rich phytoplankton from the frequent upwelling events along the south coast.

(Wepener and Degger, 2020) during a summer survey conducted in 2008, which aimed to determine metal concentrations in brown mussels (Perna perna) from buoys along the coast of South Africa, found that concentrations of $\mathrm{Al}, \mathrm{Fe}, \mathrm{Mn}, \mathrm{Zn}$, and $\mathrm{U}$ at Port Elizabeth were higher than at Cape Town and Durban harbors, while differences in $\mathrm{Cr}$, As, Se and $\mathrm{Sr}$ concentrations were insignificant. Our data, which are based on blue mussels (Mytilus galloprovincialis) at different spots of the Durban harbor, revealed that concentrations of $\mathrm{Zn}$ and As were lower and those of Fe were higher (610-1800 vs $210-280 \mathrm{ppm}$ ) than data presented by (Wepener and Degger, 2020). In comparison with (Wepener and Degger, 2020) at the Port Elizabeth the concentrations of $\mathrm{Cr}, \mathrm{Zn}$, and As were lower and of $\mathrm{Fe}$ was at the same level or lower (230-630 vs 420-750 ppm), and in Cape Town, the concentrations of $\mathrm{Cr}$ and As were lower, while of Fe and $\mathrm{Zn}$ they were almost equal or higher (260-1320 vs 245-340). However, the data obtained by the same authors in the 2009 survey are lower than the data obtained in 2008 by about one or two orders of magnitude and could not be compared correctly (Fe and $\mathrm{Zn}$ at Durban harbor were at the level of $3 \mathrm{ppm}$ ).

The high content of elements ( $\mathrm{Cr}, \mathrm{Co})$, which could reflect a terrigenous component (and confirmed by other non-volatile elements Sc and Th), was found at the Durban station that indicates the pollution originated from the coastal runoff. The mussels from this site also accumulated high concentrations of $\mathrm{V}, \mathrm{Cr}, \mathrm{Mn}, \mathrm{Fe}$, and $\mathrm{Ni}$, which are connected with this factor, based on the suspended material of bottom sediments (Naimo, 1995). Durban Harbour is the busiest container port in South Africa and is influenced by runoff from three contaminated rivers that transport waters from highly industrialized regions of the city of eThekwini (Moodley et al., 2016). The port is also exposed to significant quantities of domestic and industrial sewage discharges from the
Umgeni River and a submarine outfall (McClurg et al., 2006).

The maximum levels of concentrations of the elements $\mathrm{Zn}, \mathrm{As}, \mathrm{Se}, \mathrm{Br}$ and I at st. 5 (Hout Bay) reflected the anthropogenic component with low contents of $\mathrm{Al}$ and $\mathrm{Fe}$. The mussels from this site experienced chemical pressure from a fishmeal factory and a vessel repair facility (sources mentioned in Brown, 1964 and Fru, 2020).

According to our approaches and results, the safest region for the consumption of mussels among the studied sites was in the area of Plettenberg Bay. The Bok River (Saldana Bay) and Port Elizabeth are designated as relatively safe, however, their proximity to greywater outlets is unfavourable. The mussels from these stations in terms of accumulation of the studied elements revealed a high potential for selfpurification.

\section{Conclusions}

According to the estimated hazardous quotients and indexes, the levels of $\mathrm{Na}, \mathrm{Mn}, \mathrm{Fe}, \mathrm{Ni}, \mathrm{Se}, \mathrm{Sr}, \mathrm{Sb}$, and $\mathrm{U}$ determined in local mussels in the studied South African cities can be considered relatively safe and the mussels are suitable for consumption.

$\mathrm{Al}, \mathrm{Cr}$, As, and I can increase the health risk when the consumption of mussel meat exceeds $250 \mathrm{~g}$ /week per person and the maximum concentrations in mussels exceed the limits in the studied coastal zones (at stations 4 and 8). Arsenic could affect health risk when a high percentage of inorganic form is present in the total amount.

Station 1 (Port Nolloth), st. 4 (Waterfront), st. 5 (Hout Bay), and st. 8 (Durban) were characterized by high risks (HI > 1) for Al, Cr, Co, Zn, As, and $\mathrm{I}$ in the case of a consumption rate of $200 \mathrm{~g}$ /week per person.

According to the intake of the studied elements, the Plettenberg Bay, Saldanha Bay, and Port Elizabeth could be considered relatively safe cities for regular consumption of local mussels.

\section{CRediT authorship contribution statement}

P.S. Nekhoroshkov: Conceptualization, Data curation, Formal analysis, Visualization, Writing - original draft, Writing - review \& editing. J. Bezuidenhout: Conceptualization, Funding acquisition, Methodology, Supervision. M.V. Frontasyeva: Conceptualization, Methodology, Writing - review \& editing. I.I. Zinicovscaia: Methodology, Writing - review \& editing. N.S. Yushin: Data curation, Formal analysis. K.N. Vergel: Data curation, Formal analysis. L. Petrik: Conceptualization.

\section{Declaration of Competing Interest}

The authors report no declarations of interest.

\section{Acknowledgement}

This study was supported by South Africa —JINR grant \#28.12 21.01.20.

\section{References}

Bat, L., Arici, E., Öztekin, A., 2018. Human health risk assessment of heavy metals in the Black Sea: evaluating mussels. Curr. World Environ. 13 (1), 15. https://doi.org/ 10.12944/cwe.13.1.03.

Brown, A.C., 1964. Effect of Hydrogen Sulphide on Bullia (Gastropoda).

Cantillo, A.Y., 1998. Comparison of results of Mussel Watch Programs of the United States and France with worldwide mussel watch studies. Mar. Poll. Bull. 36 (9), 712-717 re, 203(4941), 205-206.

Chakrabarty, N., 2015. Arsenic toxicity: prevention and treatment. Arsenic Toxicity: Prevention and Treatment. https://doi.org/10.1201/b18734.

Chiesa, L.M., Ceriani, F., Caligara, M., Di Candia, D., Malandra, R., Panseri, S., Arioli, F., 2018. Mussels and clams from the Italian fish market is there a human exposition risk to metals and arsenic? Chemosphere 194, 644-649.

Clark, B.M., Massie, V., Hutchings, K., Brown, E., Biccard, A., Laird, M., Harmer, R., Makhosonke, A., Wright, A., Turpie, J., 2017. The State of Saldanha Bay and Langebaan Lagoon 2017. October. Technical Report. Report No. AEC 1741/1 
prepared by Anchor Environmental Consultants (Pty) Ltd for the Saldanha Bay Water Quality Forum Trust.

DOH (Department of Health), 1994. Regulations Relating to Metals in Foodstuffs (No. R.1518 9 September 1994). Foodstuffs, Cosmetics and Disinfectants Act, 1972 (Act 54 of 1972). Department of Health, South Africa.

DOH (Department of Health), 2004. Regulations Relating to Maximum Levels for Metals in (No. R.500 30 April 2004). Foodstuffs, Cosmetics and Disinfectants Act, 1972 (Act 54 of 1972). Department of Health, South Africa.

EFSA Panel on Contaminants in the Food Chain (CONTAM), 2009. Scientific Opinion on the use of cobalt compounds as additives in animal nutrition. EFSA J. 7 (12), 1-45. https://doi.org/10.2903/j.efsa.2009.1383.

EFSA Panel on Contaminants in the Food Chain (CONTAM), 2014. Scientific Opinion on the risks to public health related to the presence of chromium in food and drinking water. EFSA J. 12 (3), 3595.

EPA' IRIS, 2019. Integrated Risk Information System (IRIS) U.S. Available at. Environmental Protection Agency Chemical Assessment Summary National Center for Environmental Assessment. https://www.epa.gov/iris).

Erasmus, A., Ikenaka, Y., Nakayama, S.M., Ishizuka, M., Smit, N.J., Wepener, V., 2020. Trophic transfer of pollutants within two intertidal rocky shore ecosystems in different biogeographic regions of South Africa. Marine Pollution Bulletin 157, 111309. https://doi.org/10.1016/j.marpolbul.2020.111309.

FAOSTAT, Food and Agriculture Organization of the United Nations, 2017. Food Balance Sheets by Main Groups of Fish Species and Fish Nutritional Factors - by Selected Countries. Available at. http://www.fao.org/faostat/en/\#data/FBS.

Farrington, J.W., Tripp, B.W., Tanabe, S., Subramanian, A., Sericano, J.L., Wade, T.L., Knap, A.H., 2016. Edward D. Goldberg's proposal of "the mussel watch": reflections after 40 years. Mar. Pollut. Bull. 110 (1), 501-510.

Feldmann, J., Krupp, E.M., 2011. Critical review or scientific opinion paper: arsenosugars - a class of benign arsenic species or justification for developing partly speciated arsenic fractionation in foodstuffs? Anal. Bioanal. Chem. 399, 1735-1741. https://doi.org/10.1007/s00216-010-4303-6.

Ferrara, F., Fabietti, F., Delise, M., Bocca, A.P., Funari, E., 2001. Alkylphenolic compounds in edible molluscs of the Adriatic Sea (Italy). Environ. Sci. Technol. https://doi.org/10.1021/es010508h.

Firth, D.C., Salie, K., O'Neill, B., Hoffman, L.C., 2019. Monitoring of trace metal accumulation in two South African farmed mussel species, Mytilus galloprovincialis and Choromytilus meridionalis. Mar. Pollut. Bull. https://doi.org/10.1016/j. marpolbul.2019.03.007.

Frontasyeva, M., 2005. Scientific reviews: radioanalytical investigations at the IBR-2 reactor in Dubna. Neutron News 16 (3), 24-27.

Fru, W., 2020. Copper and Zinc in Water, Sediment and Gastropods in the Harbours of the Cape Town Metropole. Cape Peninsula University of Technology, South Africa. Doctoral dissertation.

Fung, C.N., Lam, J.C.W., Zheng, G.J., Connell, D.W., Monirith, I., Tanabe, S., Richardson, B.J., Lam, P.K.S., 2004. Mussel-based monitoring of trace metal and organic contaminants along the east coast of China using Perna viridis and Mytilus edulis. Environ. Pollut. https://doi.org/10.1016/j.envpol.2003.08.007.

Goldhaber, S.B., 2003. Trace element risk assessment: essentiality vs. toxicity. Regul. Toxicol. Pharmacol. https://doi.org/10.1016/S0273-2300(02)00020-X.

Greenberg, R.R., Bode, P., Fernandes, E.A.D.N., 2011. Neutron activation analysis: a primary method of measurement. Spectrochim. Acta Part B At. Spectrosc. 66 (3-4), 193-241.

Greenfield, R., Wepener, V., Degger, N., Brink, K., 2011. Richards Bay Harbour: metal exposure monitoring over the last 34 years. Mar. Pollut. Bull. 62 (8), 1926-1931.

Gu, Y.G., Huang, H.H., Lin, Q., 2016. Concentrations and human health implications of heavy metals in wild aquatic organisms captured from the core area of Daya bay's Fishery Resource Reserve, South China Sea. Environ. Toxicol. Pharmacol. https:// doi.org/10.1016/j.etap.2016.05.022.

Gupta, S.K., Singh, J., 2011. Evaluation of mollusc as sensitive indicatior of heavy metal pollution in aquatic system: a review. IIOAB J.

Ho, K.K.Y., Leung, K.M.Y., 2014. Organotin contamination in seafood and its implication for human health risk in Hong Kong. Mar. Pollut. Bull. https://doi.org/10.1016/j. marpolbul.2013.12.039.

Hofherr, J., Martinsohn, J., Cawthorn, D., Rasco, B., Naaum, A.M., 2016. Regulatory frameworks for seafood authenticity and traceability. Seafood Authenticity and Traceability. Academic Press, pp. 47-82.

JECFA, 2011. Evaluation of Certain Contaminants in Food: Seventy- Third [72nd] Report of the Joint FAO/WHO Expert Committee on Food Additives. Available at. World Health Organization. Https://Apps.Who.Int/Iris/Bitstream/Handle/10665/44514/ WHO_TRS_959_eng.Pdf.

JECFA, 2019. Evaluation of Certain Contaminants in Food: Eighty-seventh [87th] Report of the Joint FAO/WHO Expert Committee on Food Additives. World Health Organization.

Jovic, M., Onjia, A., Stanković, S., 2012. Toxic metal health risk by mussel consumption. Environ. Chem. Lett. https://doi.org/10.1007/s10311-011-0330-6.

Kobla, H.V., Volpe, S.L., 2000. Chromium, exercise, and body composition. Crit. Rev. Food Sci. Nutr. https://doi.org/10.1080/10408690091189167.

Korkmaz, C., Ay, Ö., Çolakfakioğlu, C., Cicik, B., Erdem, C., 2017. Heavy metal levels in muscle tissues of Solea solea, Mullus barbatus, and Sardina pilchardus marketed for consumption in Mersin, Turkey. Water Air Soil Pollut. https://doi.org/10.1007/ s11270-017-3503-5.

Leblanc, J.C., Guérin, T., Noël, L., Calamassi-Tran, G., Volatier, J.L., Verger, P., 2005. Dietary exposure estimates of 18 elements from the 1st French Total Diet Study. Food Addit. Contam. https://doi.org/10.1080/02652030500135367.
Leung, A.M., Braverman, L.E., 2012. Iodine-induced thyroid dysfunction. Current Opinion in Endocrinology, Diabetes and Obesity. https://doi.org/10.1097/ MED.0b013e3283565bb2.

Li, J., Qu, X., Su, L., Zhang, W., Yang, D., Kolandhasamy, P., Li, D., Shi, H., 2016. Microplastics in mussels along the coastal waters of China. Environ. Pollut. https:// doi.org/10.1016/j.envpol.2016.04.012.

Lin, H.T., Wong, S.S., Li, G.C., 2004. Heavy metal content of rice and shellfish in Taiwan. J. Food Drug Anal. https://doi.org/10.38212/2224-6614.2649.

McClurg, T.P., Parsons, G.A., Pillay, S., Newman, B.K., 2006. Sea Disposal of Sewage: Environmental Surveys in the Durban Outfalls Region-surveys Made in 2006. CSIR Report No. CSIR/NRE/PW.

Moodley, K., Pillay, S., Pather, K., Ballabh, H., 2016. Seasonal discharge and chemical flux variations of rivers flowing into the Bayhead canal of Durban Harbour, South Africa. Acta Geochim. 35 (4), 340-353.

MPHC (Ministry of Public Health of China), 2012. Chinese National Standard of Maximum Levels of Contaminants in Food specifies. (GB 2762-2012).

Munoz, O., Vélez, D., Montoro, R., 1999. Optimization of the solubilization, extraction and determination of inorganic arsenic [As(III) $+\mathrm{As}(\mathrm{v})]$ in seafood products by acid digestion, solvent extraction and hydride generation atomic absorption spectrometry. Analyst. https://doi.org/10.1039/a809426h.

Nagpal, N.K., 2004. Technical Report, Water Quality Guidelines for Cobalt (p. 59). Water Protection Section, Water, Air and Climate Change Branch, Ministry of Water, Land and Air Protection.

Naimo, T.J., 1995. A review of the effects of heavy metals on freshwater mussels. Ecotoxicology 4 (6), 341-362

Nauen, C.E., 1983. Compilation of Legal Limits for Hazardous Substances in Fish and Fishery Products. FAO Fisheries Circular (FAO). no. 764.

NDoH (National Department of Health), 2019. Statistics South Africa (Stats SA), South African Medical Research Council (SAMRC), and ICF. 2019. South Africa Demographic and Health Survey 2016. NDoH, Stats SA, SAMRC, and ICF, Pretoria, South Africa, and Rockville, Maryland, USA.

Pavlov, S.S., Dmitriev, A.Y., Frontasyeva, M.V., 2016. Automation system for neutron activation analysis at the reactor IBR-2, Frank Laboratory of neutron physics, Joint Institute for Nuclear Research, Dubna, Russia. J. Radioanal. Nucl. Chem. 309 (1), 27-38.

Richir, J., Gobert, S., 2014. The effect of size, weight, body compartment, sex and reproductive status on the bioaccumulation of 19 trace elements in rope-grown Mytilus galloprovincialis. Ecol. Indic. https://doi.org/10.1016/j.ecolind.2013.06.021.

RSA-DEA (Republic of South Africa, Department of Environmental Affairs), 2018. South African Water Quality Guidelines for Coastal Marine Waters - Natural Environment and Mariculture Use. Cape Town (ZA).164 p.

Shiomi, K., 1994. Arsenic in marine organisms: chemical forms and toxicological aspects. In: Nriagu, J.O. (Ed.), Arsenic in The Environment. Part II: Human Health and Ecosystem Effects John Wiley, New York, pp. 261-282.

Sink, K., Holness, S., Harris, L., Majiedt, P., Atkinson, L., Robinson, T., Kirkman, S., Hutchings, L., Leslie, R., Lamberth, S., Kerwath, S., von der Heyden, S., Lombard, A., Attwood, C., Branch, G., Fairweather, T., Taljaard, S., Weerts, S., Cowley, P., Awad, A., Halpern, B., Grantham, H., Wolf, T., 2012. National Biodiversity Assessment 2011: Technical Report, Volume 4. Marine and Coastal Component. South African National Biodiversity Institute (SANBI), Pretoria.

Sloth, J.J., Julshamn, K., 2008. Survey of total and inorganic arsenic content in blue mussels (Mytilus edulis L.) from Norwegian fiords: revelation of unusual high levels of inorganic arsenic. J. Agric. Food Chem. https://doi.org/10.1021/jf073174+.

Smit, A.J., Roberts, M., Anderson, R.J., Dufois, F., Dudley, S.F.J., Bornman, T.G., Olbers, J., Bolton, J.J., 2013. A coastal seawater temperature dataset for biogeographical studies: large biases between in situ and remotely-sensed data sets around the coast of South Africa. PLoS One. https://doi.org/10.1371/journal. pone.0081944.

Smolders, R., Bervoets, L., Wepener, V., Blust, R., 2003. A conceptual framework for using mussels as biomonitors in whole effluent toxicity. Hum. Ecol. Risk Assess. 9 (3), 741-760.

Spada, L., Annicchiarico, C., Cardellicchio, N., Giandomenico, S., Di Leo, A., 2013. Heavy metals monitoring in the mussel Mytilus galloprovincialis from the Apulian coast (Southern Italy). Mediterr. Mar. Sci. https://doi.org/10.12681/mms.323.

Sparks, C., Odendaal, J., Snyman, R., 2014. An analysis of historical Mussel Watch Programme data from the west coast of the Cape Peninsula, Cape Town. Mar. Pollut. Bull. 87 (1-2), 374-380.

Stankovic, S., Jovic, M., Stankovic, A.R., Katsikas, L., 2012. Heavy metals in seafood mussels. Risks for human health. Environmental Chemistry for a Sustainable World. https://doi.org/10.1007/978-94-007-2442-6_9.

Statistics South Africa, 2012. Statistical release. Census (2011). Retrieved from. Author, Pretoria. http://www.statssa.gov.za/publications/p03014/p030142011.pdf.

Storelli, M.M., Marcotrigiano, G.O., 2001. Consumption of bivalve molluscs in italy: estimated intake of cadmium and lead. Food Addit. Contam. https://doi.org/ 10.1080/02652030120012.

Tam, S.Y.K., Mok, C.S., 1991. Metallic contamination in oyster and other seafood in Hong Kong. Food Addit. Contam. https://doi.org/10.1080/02652039109373982.

USEPA, 2005. Toxicological Review of Zinc and Compounds. US Environmental Protection Agency. Report, (7440-66), Washington, DC, p. 6.

USEPA (United States Environmental Protection Agency), 1989. Guidance Manual for Assessing Human Health Risks From Chemically Contaminated, Fish and Shellfish. Environmental Protection Agency. EPA-503/8-89-002, Washington: U.S.

USEPA (United States Environmental Protection Agency), 2008. Provisional Peer Reviewed Toxicity Values for Cobalt (CASRN 7440-7448-4). 
USEPA (United States Environmental Protection Agency), 2011. Exposure Factors Handbook Edition (Final); 2011. http://cfpub.epa.gov/ncea/risk/recordisplay.cfm? deid $=236252$.

USFDA (United States Food and Drug Administration), 1993. Food and Drug Administration. Guidance Document for Nickel in Shellfish. DHHS/PHS/FDA/ CFSAN/office of seafood, Washington, DC.

USFDA (United States Food and Drug Administration), 2007. Guide for the Control of Molluscan Shellfish. Guidance Documents. Chapter II. Growing areas: 04. Action levels, tolerances, and guidance levels for poisonous or deleterious substances in seafood, pp. 1-4.

Van Niekerk, L., Turpie, J.K., 2012. National Biodiversity Assessment 2011: Technical Report, Volume 3. Estuary Component. CSIR Report Number CSIR/NRE/ECOS/ER 2011/0045/B. Council for Scientific and Industrial Research, Stellenbosch.

Wepener, V., Degger, N., 2020. Monitoring metals in South African harbours between 2008 and 2009, using resident mussels as indicator organisms. African Zoology 55 (4), 267-277. https://doi.org/10.1080/15627020.2020.1799720.
Whyte, A.L.H., Raumati Hook, G., Greening, G.E., Gibbs-Smith, E., Gardner, J.P.A., 2009. Human dietary exposure to heavy metals via the consumption of greenshell mussels (Perna canaliculus Gmelin 1791) from the Bay of Islands, northern New Zealand. Sci. Total Environ. https://doi.org/10.1016/j.scitotenv.2009.04.011.

Yap, C.K., Cheng, W.H., Karami, A., Ismail, A., 2016. Health risk assessments of heavy metal exposure via consumption of marine mussels collected from anthropogenic sites. Sci. Total Environ. https://doi.org/10.1016/j.scitotenv.2016.02.092.

Zar, J.H., 1984. Critical values for Fisher's exact test. Biostatistical Analysis. PrenticeHall Englewood Cliffs, NJ, pp. 220-242.

Zinicovscaia, I., Pavlov, S.S., Frontasyeva, M.V., Ivlieva, A.L., Petritskaya, E.N., Rogatkin, D.A., Demin, V.A., 2018. Accumulation of silver nanoparticles in mice tissues studied by neutron activation analysis. J. Radioanal. Nucl. Chem. 318 (2), 985-989. 